AL, 2. 2002-9

6,2

\title{
Fish Species at Risk in the Milk and St. Mary \\ Drainages
}

Monagement Division

RESURCE STAUISAND ASSESSMENT BRANCH

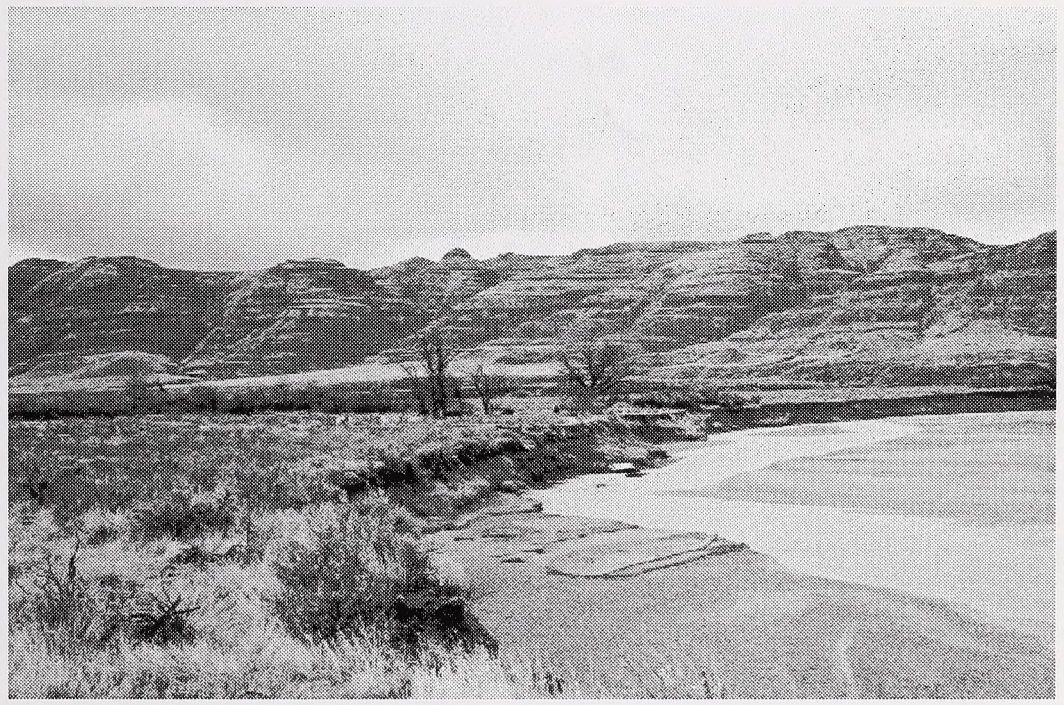

Alberta Species at Risk Interim Report 
Digitized by the Internet Archive in 2016 


\title{
FISH SPECIES AT RISK IN THE \\ MILK AND ST. MARY DRAINAGES
}

Prepared for

ALBERTA ENVIRONMENT

Natural Resources Service

Prairie Region

\author{
Prepared by \\ RL\&L ENVIRONMENTAL SERVICES LTD. \\ 17312 - 106 Avenue \\ Edmonton, Alberta \\ T5S $1 \mathrm{H} 9$ \\ Phone: (780) 483-3499
}

Alberta Species at Risk Interim Report

March 2001 
Publication No. I/029

ISBN: 0-7785-1817-5 Published Edition)

ISBN: 0-7785-1818-3 (On-line Edition)

ISSN: 1496-7219 (Published Edition)

ISSN: 1496-7146 (On-line Edition)

Cover Photo: Lower Milk River at the Pinhorn Ranch, October 2000

For copies of this report, contact:

Information Center- Publications

Alberta Environment

Natural Resources Service

Main Floor, Great West Life Building 9920- 108 Street

Edmonton, Alberta, Canada T5K 2M4

Telephone: (780) 422-2079

OR

Information Service

Alberta Environment

$\# 100,3115$ - 12 Street NE

Calgary, Alberta, Canada T2E 7J2

Telephone: (403) 297- 3362

OR

Visit our web site at:

http://www.gov.ab.ca/env/fw/status/reports/index.html

This publication can be cited as:

RL\&L Environmental Services Ltd. 2001. Fish species at risk in the Milk and St. Mary drainages. Alberta Sustainable Resource Development, Fisheries and Wildlife Management Division, Edmonton, Alberta. Interim Report. 


\section{ACKNOWLEDGEMENTS}

RL\&L Environmental Services Ltd. would like to thank Terry Clayton and Richard Quinlan of Alberta Environment for providing us with the opportunity to become involved in this project and for contributing information and guidance during the study. We would also like to thank Sue Cotterill of Alberta Environment (Species at Risk biologist) for her enthusiastic participation during the fall sampling session. The following staff members of RL\&L Environmental Services Ltd. participated in the field program and report preparation:

$\begin{array}{ll}\text { Jim O’Neil } & \text { Project Advisor and Senior Editor } \\ \text { Alison Little } & \text { Project Manager and Author } \\ \text { Chantal Pattenden } & \text { Senior Biological Technician } \\ \text { Kent Kristensen } & \text { Biological Technician } \\ \text { Charlene Williamson } & \text { Biological Technician } \\ \text { Diane Starr } & \text { Administration Support/Report Production }\end{array}$




\section{TABLE OF CONTENTS}

Page \#

ACKNOWLEDGEMENTS i

LIST OF TABLES iii

LIST OF FIGURES iv

1.0 INTRODUCTION 1

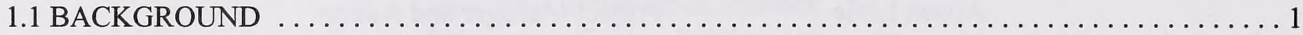

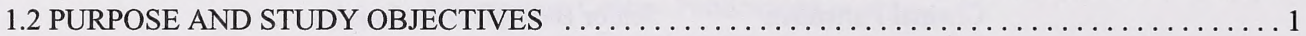

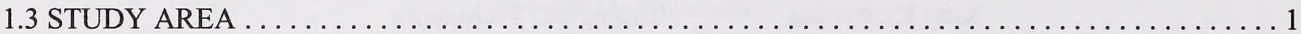

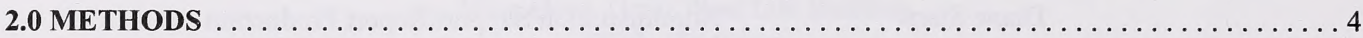

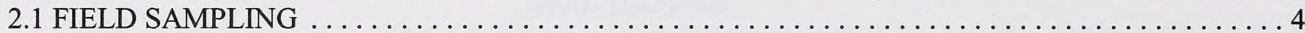

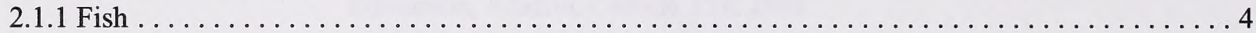

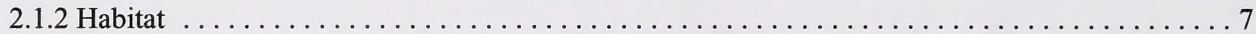

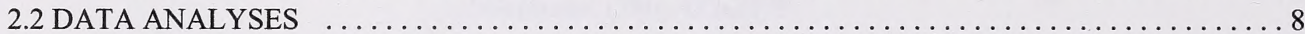

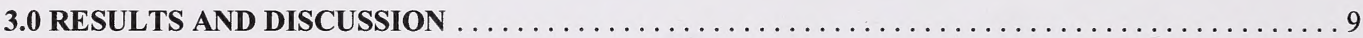

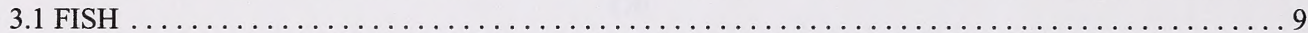

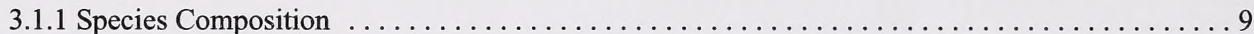

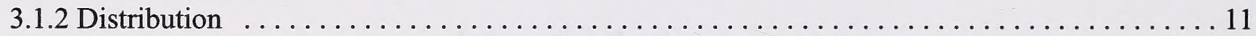

3.1.3 Fish Abundance ............................................ 19

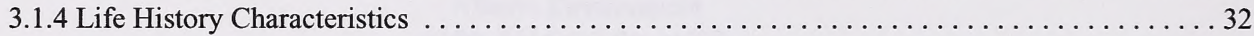

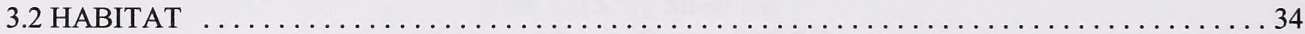

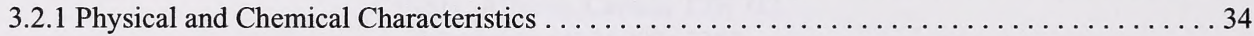

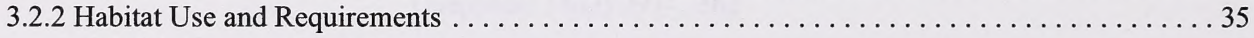

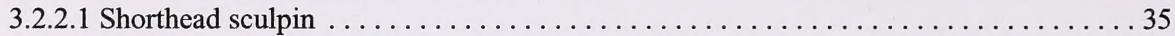

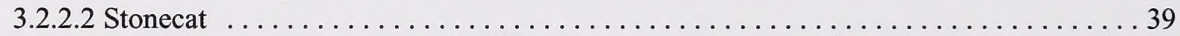

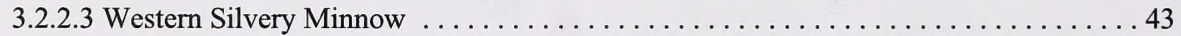

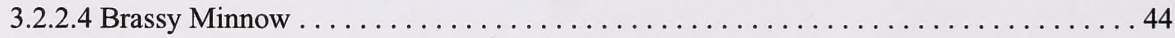

3.2.2.5 Sauger . . . . . . . . . . . . . . . . . . . . . . . . . . 45

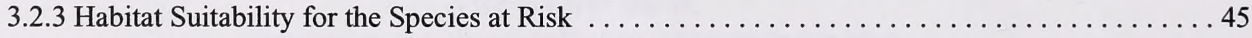

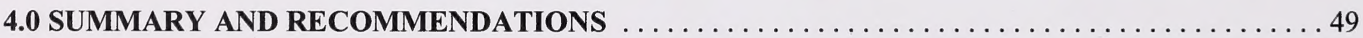

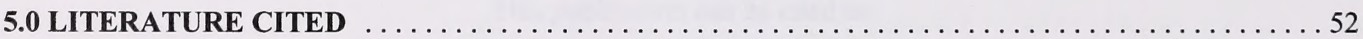

APPENDIX A SITE DATA

APPENDIX B HABITAT CLASSIFICATION SYSTEM

APPENDIX C FISH DATA 


\section{LIST OF TABLES}

Page \#

Table 3.1 Overall percent composition of fish species encountered in the Milk and St. Mary drainages,

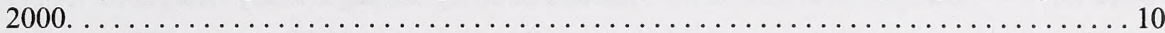

Table 3.2 Seasonal percent composition of fish species encountered in the Milk and St. Mary

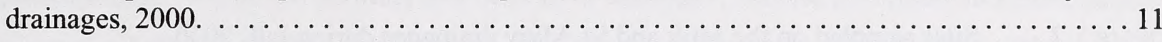

Table $3.3 \quad$ Numbers and percent composition of fish species encountered in the mainstem Milk River during 1969, 1979-80, and 1986.

Table 3.4 Seasonal relative abundances (no. fish $/ \mathrm{min}$ ) for species encountered by backpack electrofishing in the Milk and St. Mary drainages, 2000.

Table 3.5 Seasonal relative abundances (no. fish $/ 100 \mathrm{~m}^{2}$ ) for fish species captured by beach seining

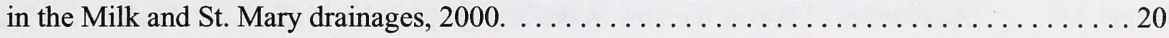

Table 3.6 Relative abundance (no. fish $/ 100 \mathrm{~m}^{2}$ ) by site for fish species captured using beach seines in the Milk and St. Mary drainages, 2000.

Table 3.7 Length differences between sample sites for the Species of Concern in the Milk and St. Mary

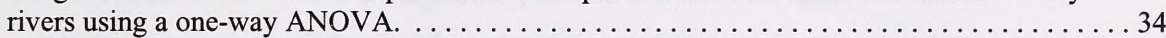

Table 3.8 Summary of physical and chemical characteristics in the Milk and St. Mary drainages,

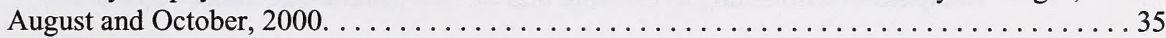

Table 3.9 Percent occurrence of habitat types in areas where shorthead sculpin were captured in the

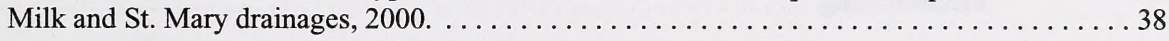

Table $3.10 \quad$ Summary of habitat variables for stonecat in the Milk River, $2000 . \ldots \ldots \ldots$

Table 3.11 Summary of habitat variables for sauger in the Milk River, $2000 . \ldots \ldots$ 


\section{LIST OF FIGURES}

Page \#

Figure $1.1 \quad$ Fish Species at Risk in the Milk and St. Mary drainages Study Area, 2000. ......... 3

Figure $2.1 \quad$ Sites sampled on the Milk and St. Mary drainages during summer, $2000 \ldots \ldots \ldots \ldots \ldots$

Figure $2.2 \quad$ Sites sampled on the Milk and St. Mary drainages during fall, $2000 \ldots \ldots \ldots \ldots \ldots \ldots$

Figure $3.1 \quad$ Distribution of shorthead sculpin in the Milk and St. Mary rivers. $\ldots \ldots \ldots \ldots \ldots \ldots \ldots$

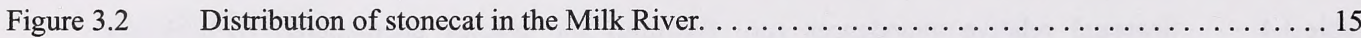

Figure 3.3 Distribution of western silvery minnow in the Milk River. $\ldots \ldots \ldots \ldots \ldots \ldots \ldots \ldots \ldots$

Figure $3.4 \quad$ Distribution of brassy minnow in the Milk River. $\ldots \ldots \ldots \ldots \ldots \ldots \ldots \ldots \ldots \ldots \ldots \ldots \ldots \ldots \ldots \ldots$

Figure $3.5 \quad$ Distribution of sauger in the Milk River. $\ldots \ldots \ldots \ldots \ldots \ldots \ldots \ldots \ldots \ldots \ldots \ldots \ldots \ldots \ldots$

Figure 3.6 Relative abundance (no. fish/min) of shorthead sculpin encountered using backpack

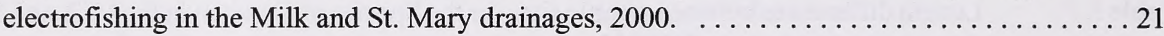

Figure 3.7 Relative abundance (no. fish/min) of stonecat, sauger, brassy minnow encountered using backpack electrofishing in the Milk and St. Mary drainages, $2000 \ldots \ldots \ldots \ldots \ldots \ldots \ldots \ldots$

Figure 3.8 Relative abundance of shorthead sculpin in the Milk and St. Mary rivers using backpack

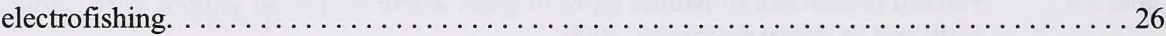

Figure 3.9 Relative abundance of shorthead sculpin in the Milk and St. Mary rivers using beach

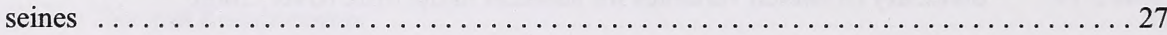

Figure $3.10 \quad$ Relative abundance of stonecat in the Milk River. . . . . . . . . . . . . . . 28

Figure 3.11 Relative abundance of western silvery minnow in the Milk River. . . . . . . . . . . 29

Figure 3.12 Relative abundance of brassy minnow in the Milk River. $\ldots \ldots \ldots \ldots \ldots \ldots \ldots \ldots \ldots$

Figure 3.13 Relative abundance of sauger in the Milk River. $\ldots \ldots \ldots \ldots \ldots \ldots \ldots \ldots \ldots \ldots \ldots \ldots \ldots$

Figure 3.14 Length frequency distribution of shorthead sculpin in the Milk and St. Mary drainages,

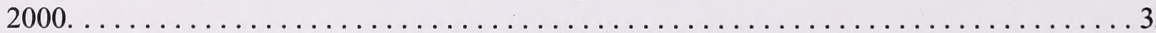

Figure 3.15 Daily water temperatures at three sites in the Milk and St. Mary drainages (August to

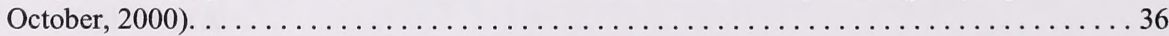

Figure 3.16 Historical discharge for the months of August, October, and December in the Milk River at the Town of Milk River. . . . . . . . . . . . . . . . . . . . . . . . . . . . . 37

Figure 3.17 Linear regressions of habitat variables and relative abundance (CPUE, no. fish $/ \mathrm{min}$ ) for shorthead sculpin in the Milk and St. Mary drainages, $2000 \ldots \ldots \ldots \ldots \ldots \ldots \ldots \ldots \ldots \ldots \ldots \ldots$

Figure 3.18 Confirmed overwintering sites for shorthead sculpin in the Milk River. . . . . . . . . 46 


\subsection{INTRODUCTION}

\subsection{BACKGROUND}

Alberta Environment, Fisheries and Wildlife Management Division has initiated studies to assess the distribution and relative abundance of "Species at Risk" throughout Alberta in accordance with the National Accord for the Protection of Species at Risk. Within the St. Mary and Milk river drainages, Alberta Environment identified three fish species of concern including the St. Mary shorthead sculpin (Cottus sp.), western silvery minnow (Hybognathus argyritis), and the stonecat (Noturus flavus). Although not listed as a "Species at Risk", Alberta Environment is interested in the status of the brassy minnow (Hybognathus hankinsoni) and sauger (Stizostedion canadense). Hereafter, all five aforementioned species will be referred to as "Species of Concern".

\subsection{PURPOSE AND STUDY OBJECTIVES}

In assessing the status of the fish Species of Concern within the Milk and St. Mary river drainages, it was necessary to address two primary questions:

Are the populations of the St. Mary shorthead sulpin, western silvery minnow, and stonecat increasing, stable or declining?

What habitat variables are key to ensuring the continued viability of the Species of Concern?

The specific objectives of the present study were:

Define and document the seasonal distribution and relative abundance of the Species of Concern;

Compare seasonal relative abundance of fish species during the 2000 study with historical data;

Identify potential critical habitats for the three Species at Risk;

Collect information on fish species composition by river reach;

Characterize the habitats utilized for the Species of Concern; and

Measure physical and chemical parameters at sampling sites.

\subsection{STUDY AREA}

The study area included the mainstem of the Milk, North Milk, and St. Mary rivers, and Lee Creek (a major tributary to the St. Mary River) within Alberta. The length of river investigated was extensive, with the Milk River extending approximately $270 \mathrm{~km}$, the North Milk River $90 \mathrm{~km}$, and the St. Mary River extending $40 \mathrm{~km}$ above the reservoir (Figure 1.1).

The Milk River and St. Mary River systems are influenced by water diversions for irrigation purposes. In 1917, the St. Mary Canal was built to divert irrigation waters from the St. Mary River to the North Milk River. The canal runs from the St. Mary River near Babb, Montana to approximately $8 \mathrm{~km}$ south of the international boundary where water 
is transferred to the North Milk River. Irrigation waters are generally diverted into the North Milk River beginning in April, and normally continue to October. Peak monthly flows generally occur during May to July as a result of the diverted flow. Mean monthly flows at the town of Milk River for the period 1909 to 2000 ranged between 9.3 and $19.2 \mathrm{~m}^{3} / \mathrm{s}$ for the months of April to September, and were $<3 \mathrm{~m}^{3} / \mathrm{s}$ between October and December (data obtained by Water Survey Canada, Jan 2001). 


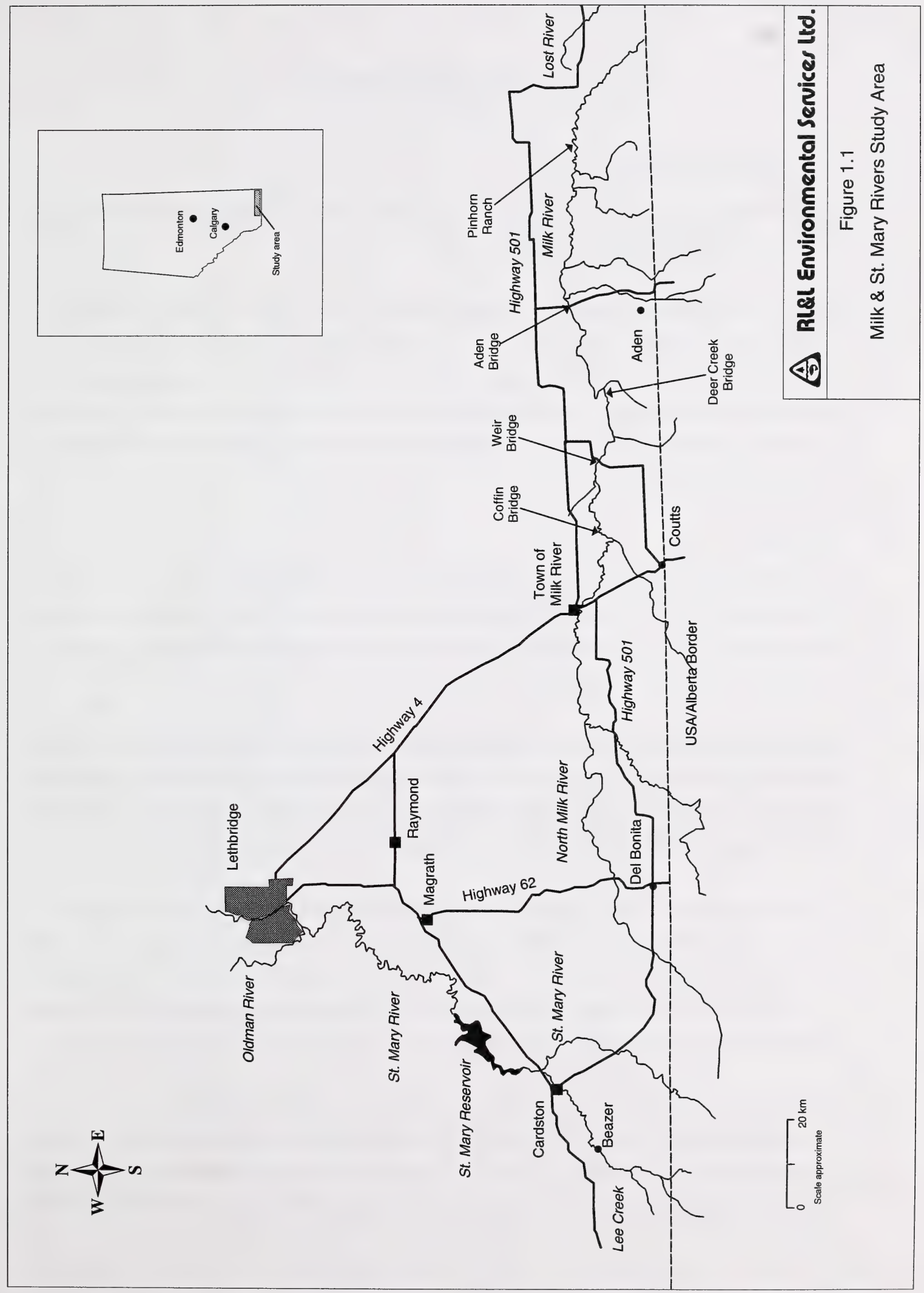




\subsection{METHODS}

\subsection{FIELD SAMPLING}

The 2000 field program was conducted during summer ( 7 and 16 August) and fall (17 and 23 October) by a twoperson crew. Access to sites was by 4 -wheel drive truck.

In total, 20 sites were assessed during each the summer and fall (Figures 2.1 and 2.2; Appendix A - Site Data). The summer program included 10 sites on the Milk River, six on the St. Mary River, and four on Lee Creek. During fall, the majority of the 20 sample sites were located on the Milk River. The decision to reduce sampling effort to two sites in the St. Mary Drainage was based on the fact that shorthead sculpin were the only Species of Concern located in this drainage and they had been previously recorded at all sample sites during summer, except the two most upper sites in Lee Creek.

\subsubsection{Fish}

During the summer survey, three fish sampling techniques were utilized: boat electrofishing, backpack electrofishing and beach seining. Typically, only two sample methods were used at each site to ensure that all species and lifestages were captured. Sampling methods chosen at a given site were determined by sampling conditions (i.e., substrate type, velocities, and water depth).

Boat electrofishing was used during the initial stages of the summer session $(n=4)$ to determine the effectiveness of this method for capturing the Species of Concern. When it became apparent that this method was ineffective in comparison to the two other methods, it was discontinued. Boat electrofishing is generally most effective at capturing larger-sized fish $(>250 \mathrm{~mm}$ ) which were not a priority in the present study (except sauger).

The boat electrofisher was operated from an inflatable double-bowed drift boat fitted with a rowing frame. The electrofishing unit consisted of a Smith-Root Type VIA powered by a $4000 \mathrm{~W}$ Generac generator. Two anodes positioned on fixed booms extended from the bow; each anode consisted of six-dropper cables (surface area $=188 \mathrm{~cm}^{2}$ ). The boat was equipped with a cathode comprised of 18 dropper cables (surface area $=565 \mathrm{~cm}^{2}$ ) situated at the stern. Amperage output ranged from 3.0 to $6.0 \mathrm{~A}$ at a pulse frequency of $60 \mathrm{~Hz}$ using direct current.

Sampling consisted of electrofishing while drifting in a downstream direction. One individual of the two-person crew was situated at the bow of the boat and netted immobilized fish, while the other person navigated. Captured fish were immediately placed in a $30 \mathrm{~L}$ live-well. At the end of each electrofishing section the observed and captured fish were enumerated and measured (fork length). All captured fish were released into suitable holding water. 


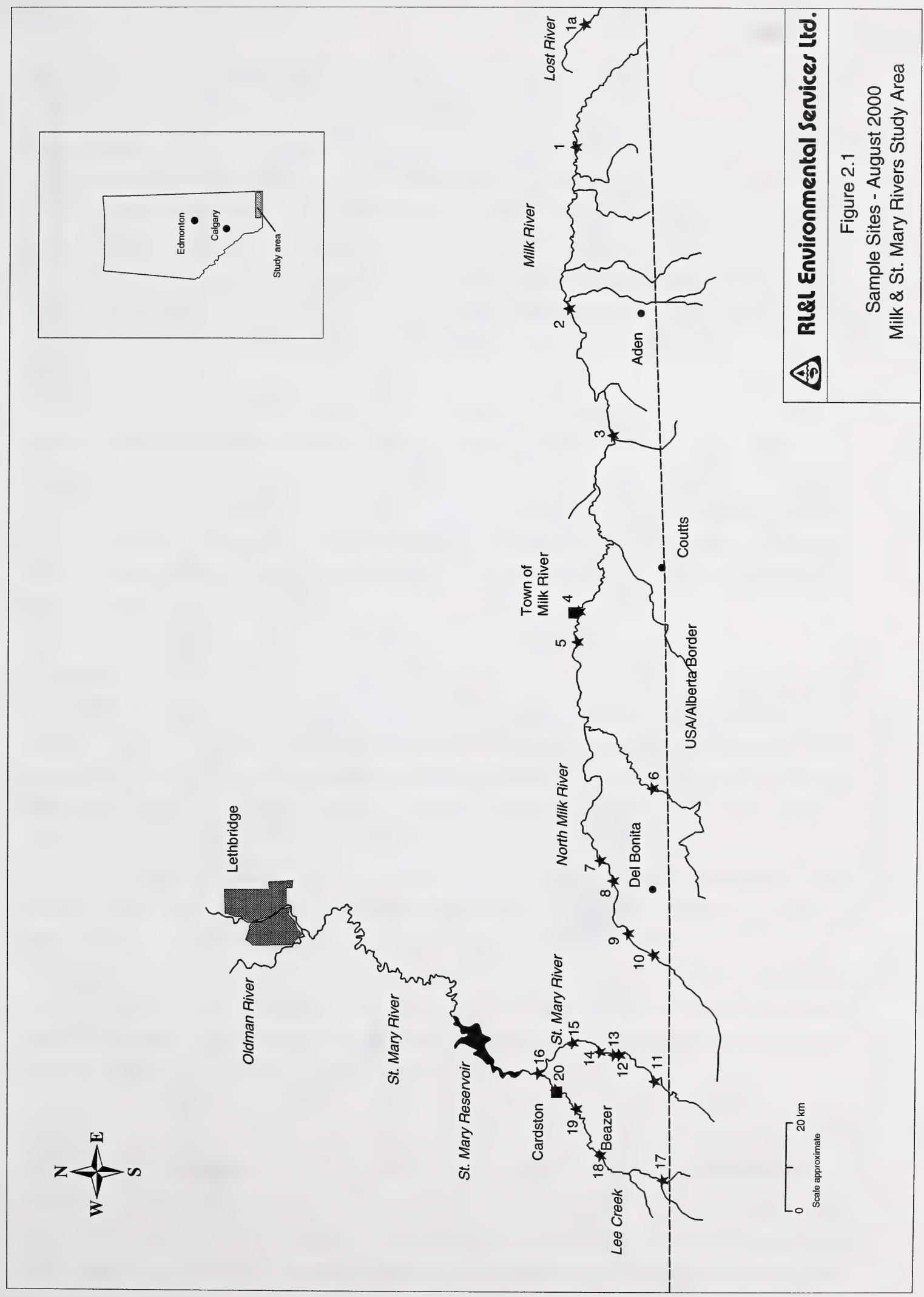




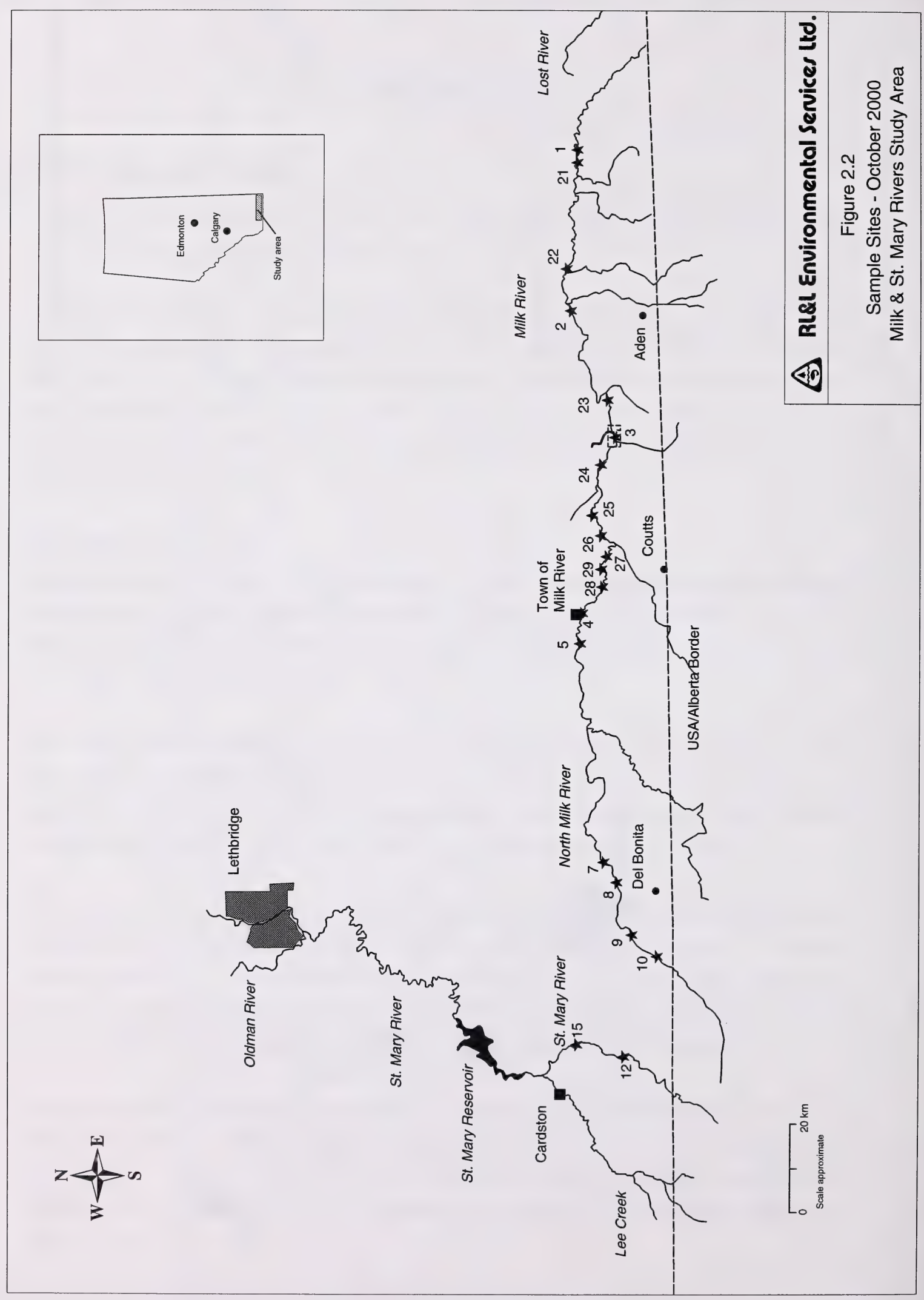


Beach seining was used to sample habitats exhibiting low to moderate water velocities $(<0.7 \mathrm{~m} / \mathrm{s})$. Where possible (i.e., sufficient area with suitable substrate, depth and velocity), three hauls (each $25 \mathrm{~m}$ in length) were completed at each site using a $6.0 \mathrm{~m}$ long beach seine with a mesh size of $5 \mathrm{~mm}$; exceptions being at Site 8 during the summer where the length of beach seine was $4.0 \mathrm{~m}$. Information recorded at seine haul sites included location (UTM coordinates), depth (m), substrate composition, haul length (m), width (m), and sampling efficiency. Stream velocity was also measured at three points along the haul using a Swoffer Model 2100 digital flow meter (inshore, mid, and offshore). Captured fish species were enumerated. Fork length was measured for all specimens of the Species of Concern. For the "other" fish species, some of which were present in large numbers, only a subsample of fork lengths were recorded for each species (minimum of 10/species per site).

A Smith-Root Type XII high output backpack electrofisher was utilized to sample fish in areas which were not suitable for seining. The electrofisher operator waded in the channel in an upstream direction, and sampled in the vicinity of suspected fish holding areas (undercut banks, boulder cover, etc.). The netter, who was positioned immediately downstream, collected the fish and placed them in a holding bucket. Pertinent data recorded at each sample site included UTM coordinates, date and time of day, water temperature, distance sampled $(\mathrm{m})$, sampling effort (s), habitat conditions (depth, substrate, cover type, etc.), electrofisher settings, as well as the number and species of fish captured or observed.

\subsubsection{Habitat}

Aquatic habitats were characterized at each sample site according to the method of O'Neil and Hildebrand 1986 (Appendix B). This method has been used extensively throughout streams and rivers in southern Alberta, including previous studies on the Milk River. The procedure differentiates stream habitat into discrete habitat units according to type (e.g., run, riffle, pool) and quality (takes into account depth and cover). This system provides an efficient method for describing and rating physical habitat capability. Detailed mesohabitat characteristics were recorded at each site (e.g., habitat type and channel and wetted widths). Microhabitat characteristics were recorded where Species of Concern were captured; these included water depth and velocity at capture location, substrate composition (\%), substrate size, availability (\%) of instream cover types, silt depth, and D90. Substrate composition and instream cover types were visually assessed as a percentage of the area within a $1 \mathrm{~m}$ radius of the capture location of Species of Concern. Substrate size was determined by recording 10 random measurements on substrate within a $1 \mathrm{~m}$ radius of the capture location. D90 represented the intermediate diameter of the bed material particle size that was greater than $90 \%$ of all substrate present in the channel.

Water conductivity and $\mathrm{pH}$ were measured with an Oakton TDSTestr $3( \pm 1.0 \mu \mathrm{S} / \mathrm{cm})$ and an Oakton $\mathrm{pHTestr} 2( \pm 0.1)$, respectively. Turbidity samples were collected from each site, preserved and measured in the laboratory with an Orbeco-Hellige Model 966 meter $( \pm 0.01 \mathrm{NTU})$. Dissolved oxygen concentrations $( \pm 0.01 \mathrm{mg} / \mathrm{L})$ and temperature $\left( \pm 0.1^{\circ} \mathrm{C}\right)$ were measured at each site using an Oxyguard Handy Beta dissolved oxygen-temperature meter. Water 
temperature was continuously monitored (30 min intervals) at three locations within the study area during part of the open water season (early August to late October) using Vemco Minilog-TR thermographs. Discharge data for the Milk and St. Mary rivers were obtained from Water Survey Canada (Stations 11AA0005 and 05AE027, respectively).

\subsection{DATA ANALYSES}

Relative abundance of fish was calculated in terms of catch-per-unit-effort (CPUE) based on the number of captured fish per unit of effort which was dependent on the sampling method. For backpack electrofishing, CPUE was expressed as number of fish/min. Observed fish were included in the backpack electrofishing catch totals to more accurately reflect species abundance and composition. Beach seining catch rates were calculated as the number of fish $/ 100 \mathrm{~m}^{2}$ for each species.

A One-way Analysis of Variance (ANOVA) was used to determine statistical differences in the mean size of the Species of Concern between sites. Where results were significant, a post hoc range test (Dunnett's $\mathrm{C}$ for unequal variance) was performed to determine which sites contributed to the significant differences in mean fork length. Statistical significance was accepted at $\mathrm{P}<0.05$.

Pearson Correlation and Linear Regression Analysis were used to assess the relationship between habitat variables and fish abundance for shorthead sculpin. In contrast, these analyses were not performed for the other Species of Concern due to the low sample sizes. However, sample sizes for stonecat were adequate to perform a One-sample T-test to determine the statistical significance for each of the habitat variables. 


\subsection{RESULTS AND DISCUSSION}

\subsection{FISH}

\subsubsection{Species Composition}

In total, 4911 fish were encountered in the Milk and St. Mary drainages, representing 16 fish species (Table 3.1; Appendix C - list of species). Of these, 3234 fish were encountered in the Milk River (representing 14 species), 526 fish in the St. Mary River (7 species), and 1151 fish in Lee Creek (7 species). Of the Species of Concern, all five species were encountered in the Milk River. In the other two systems, shorthead sculpin was the only fish Species of Concern encountered. This was expected since the St. Mary River drainage is located outside the geographical range for the other Species of Concern.

Overall, flathead chub dominated the catch in the Milk River (33\%), followed by sucker species (29\% combined), and longnose dace (26\%). In the St. Mary River, longnose dace represented $61 \%$ of the composition, followed by shorthead sculpin (28\%). In Lee Creek, longnose dace were numerically dominant $(82 \%)$, followed by sucker species (15\%), and shorthead sculpin (3\%).

Species composition varied seasonally in both the Milk and St. Mary rivers. In the Milk River during summer, longnose dace dominated the sample (48\%), followed by sucker species (42\%; Table 3.2). However, during fall, flathead chub made the largest contribution (44\%), followed by sucker species (24\%), longnose dace (17\%), and shorthead sculpin (12\%).

In the St. Mary River during summer, the catch was comprised primarily of longnose dace ( $71 \%)$, followed by shorthead sculpin (21\%). In contrast, during fall, shorthead sculpin represented the highest contribution to the catch (52\%), followed by longnose dace (26\%). Lee Creek was sampled only during summer, where longnose dace dominated the sample at this time $(82 \%)$.

Shorthead sculpin represented a greater proportion of the catch during the fall than during summer in both the Milk and St. Mary rivers. In the Milk River, the percentage contribution increased from $4 \%$ during summer to $12 \%$ during fall. Similarly, in the St. Mary River, the contribution of shorthead sculpin increased from $21 \%$ to $52 \%$.

Brassy minnow and sauger represented similar percentages in composition during both summer and fall. While stonecat and western silvery minnow were present only during fall sampling. These Species of Concern represented low numbers of the catch during all seasons sampled.

Species composition in the present study was similar to those recorded in 1969 and 1986 (Tables 3.1 and 3.3). In general, sucker species, longnose dace, and flathead chub dominated the samples for each of the years of study. Of the Species of Concern, species composition between years was relatively similar. Shorthead sculpin were the only 
species that varied slightly between years. In 1969, shorthead sculpin represented $1.1 \%$, while in 1986 they represented $4.8 \%$ and in 2000, sculpins represented $9.7 \%$. All other Species of Concern represented $<1.5 \%$ of the overall composition in 1969, 1986, and 2000.

Studies conducted by Clayton and Ash (1980) differed from that obtained during the other studies $(1969,1986$, and 2000), likely because this study was conducted during late November and February, and the other studies were conducted during open water periods (primarily summer and fall). Clayton and Ash (1980) reported that shorthead sculpin were the dominant species (43.7\%) during late fall and winter, followed by longnose dace $(36.1 \%)$. Stonecat also represented a higher percent composition than the other studies, representing $5.9 \%$.

A study currently being conducted by in the Milk River between the International Boundary Crossing to the Fresno Reservoir in Montana documented ten fish species (per. com. Sean Stash, Montana State University). Flathead chub were by far the most dominant species ( $85.9 \%$ composition), followed by western silvery minnow $(5.8 \%)$. Sauger represented $2.5 \%$ of the composition and stonecat represented $1.3 \%$.

Table 3.1 Overall percent composition of fish species encountered in the Milk and St. Mary drainages, 2000.

\begin{tabular}{|c|c|c|c|c|c|c|}
\hline \multirow[b]{2}{*}{ Species } & \multicolumn{2}{|c|}{ Milk River } & \multicolumn{2}{|c|}{ St. Mary River } & \multicolumn{2}{|c|}{ Lee Creek } \\
\hline & No. & Percent & No. & Percent & No. & Percent \\
\hline Brassy minnow & 9 & 0.3 & - & & & \\
\hline Sauger & 19 & 0.6 & - & & & \\
\hline Shorthead sculpin & 314 & 9.7 & 146 & 27.8 & 33 & 2.9 \\
\hline Stonecat & 34 & 1.1 & - & & & \\
\hline Western silvery minnow & 2 & 0.1 & - & & & \\
\hline Burbot & 4 & 0.1 & & & & \\
\hline Cutthroat trout & & & & & 3 & 0.3 \\
\hline Rainbow trout & & & & & 2 & 0.2 \\
\hline Mountain whitefish & 1 & $<0.1$ & 21 & 4.0 & & \\
\hline Flathead chub & 1064 & 32.9 & & & & \\
\hline Lake chub & 22 & 0.7 & & & 1 & 0.1 \\
\hline Longnose dace & 836 & 25.9 & 323 & 61.4 & 941 & 81.8 \\
\hline Longnose sucker & 89 & 2.8 & 7 & 1.3 & & \\
\hline Mountain sucker & 34 & 1.1 & 3 & 0.6 & 93 & 8.1 \\
\hline White sucker & 11 & 0.3 & 2 & 0.4 & 1 & 0.1 \\
\hline Sucker spp. & 793 & 24.5 & 15 & 2.9 & 76 & 6.6 \\
\hline Trout-perch & 1 & $<0.1$ & 8 & 1.5 & & \\
\hline Unidentified & 1 & $<0.1$ & 1 & 0.2 & 1 & 0.1 \\
\hline Total & 3234 & 100.0 & 526 & 100.0 & 1151 & 100 \\
\hline
\end{tabular}


Table 3.2 Seasonal percent composition of fish species encountered in the Milk and St. Mary drainages, 2000 .

\begin{tabular}{|c|c|c|c|c|c|c|c|c|c|c|}
\hline \multirow{3}{*}{ Species } & \multicolumn{4}{|c|}{ Milk River } & \multicolumn{4}{|c|}{ St. Mary River } & \multirow{2}{*}{\multicolumn{2}{|c|}{$\frac{\text { Lee Creek }}{\text { Summer }}$}} \\
\hline & \multicolumn{2}{|c|}{ Summer } & \multicolumn{2}{|c|}{ Fall } & \multicolumn{2}{|c|}{ Summer } & \multicolumn{2}{|c|}{ Fall } & & \\
\hline & No. & Percent & No. & Percent & No. & Percent & No. & Percent & No. & Percent \\
\hline Brassy minnow & 1 & 0.1 & 8 & 0.3 & - & & - & & - & \\
\hline Sauger & 1 & 0.1 & 18 & 0.8 & - & & - & & - & \\
\hline Shorthead sculpin & 38 & 4.2 & 276 & 11.8 & 89 & 21.4 & 57 & 51.8 & 33 & 2.9 \\
\hline Stonecat & & & 34 & 1.5 & - & & - & & - & \\
\hline Western silvery minnow & & & 2 & 0.1 & - & & - & & - & \\
\hline Burbot & 1 & 0.1 & 3 & 0.1 & & & & & & \\
\hline Cutthroat trout & & & & & & & & & 3 & 0.3 \\
\hline Rainbow trout & & & & & & & & & 2 & 0.2 \\
\hline Mountain whitefish & & & 1 & 0 & 21 & 5.0 & & & & \\
\hline Flathead chub & 45 & 5.0 & 1019 & 43.7 & & & & & & \\
\hline Lake chub & 4 & 0.4 & 18 & 0.8 & & & & & 1 & 0.1 \\
\hline Longnose dace & 437 & 48.4 & 399 & 17.1 & 294 & 70.7 & 29 & 26.4 & 941 & 81.8 \\
\hline Longnose sucker & 26 & 2.9 & 63 & 2.7 & 7 & 1.7 & & & & \\
\hline Mountain sucker & 9 & 1.0 & 25 & 1.1 & & & 3 & 2.7 & 93 & 8.1 \\
\hline White sucker & I & 0.1 & 10 & 0.4 & & & 2 & 1.8 & 1 & 0.1 \\
\hline Sucker spp. & 340 & 37.7 & 453 & 19.4 & I & 0.2 & 14 & 12.7 & 76 & 6.6 \\
\hline Trout-perch & & & 1 & 0 & 3 & 0.7 & 5 & 4.5 & & \\
\hline Unidentified & & & 1 & 0 & 1 & 0.2 & & & 1 & 0.1 \\
\hline Total & 903 & 100.0 & 2331 & 100.0 & 416 & 100 & 110 & 100 & 1151 & 100 \\
\hline
\end{tabular}

\subsubsection{Distribution}

The Milk River basin is unique in Alberta since it is the only river in the Province that contributes to the Missouri River drainage. As a result, one member of the provincial fish species assemblage (i.e., stonecat) occurs only in the Milk River. The Milk River also contains species that are restricted in distribution in Alberta, such as the western silvery minnow, shorthead sculpin, and brassy minnow (RL\&L 1987).

The following section provides a description of the distribution within Canada and Alberta, and provides distribution maps within the Milk and St. Mary drainages for the Species of Concern (Figures 3.1 to 3.5).

\section{Shorthead Sculpin}

The shorthead sculpin occurs in southern British Columbia (primarily in the Columbia River drainage) and in southern Alberta. In Alberta, the shorthead sculpin are known only from the St. Mary and Milk river drainages (Roberts 1988; Nelson and Paetz 1992; Paetz 1993). This species likely moved into the Milk River from the St. Mary River by irrigation canals in Montana (Nelson and Paetz 1992). 
Table 3.3 Numbers and percent composition of fish species encountered in the mainstem Milk River during 1969, 1979-80, and 1986.

\begin{tabular}{|c|c|c|c|c|c|c|}
\hline \multirow[t]{2}{*}{ Species } & \multicolumn{2}{|c|}{ Willock (1969) } & \multicolumn{2}{|c|}{ Clayton and Ash (1980) } & \multicolumn{2}{|c|}{ RL\&L (1987) } \\
\hline & No. & Percent & No. & Percent & No. & Percent \\
\hline Brassy minnow & & & & & 12 & 0.1 \\
\hline Sauger & 15 & 0.1 & & & 76 & 0.4 \\
\hline Shorthead sculpin & 155 & 1.1 & 214 & 43.7 & 1009 & 4.8 \\
\hline Stonecat & 35 & 0.2 & 29 & 5.9 & 3 & $<0.1$ \\
\hline Western silvery minnow & 3 & $<0.1$ & 2 & 0.4 & 10 & $<0.1$ \\
\hline Mountain whitefish & 22 & 0.2 & & & 137 & 0.7 \\
\hline Northern pike & 40 & 0.3 & & & 32 & 0.2 \\
\hline Burbot & 1 & $<0.1$ & 4 & 0.8 & 1 & $<0.1$ \\
\hline Fathead minnow & 935 & 6.5 & & & 64 & 0.3 \\
\hline Flathead chub & 1337 & 9.2 & 1 & 0.2 & 1502 & 7.1 \\
\hline Lake chub & 1129 & 7.8 & 5 & 1 & 945 & 4.5 \\
\hline Longnose dace & 2749 & 19 & 177 & 36.1 & 4241 & 20.2 \\
\hline Longnose sucker & 2983 & 20.6 & 3 & 0.6 & 4770 & 22.7 \\
\hline Mountain sucker & 1257 & 8.7 & 53 & 10.8 & 4089 & 19.4 \\
\hline White sucker & 3660 & 25.3 & 2 & 0.4 & 1537 & 7.3 \\
\hline Sucker spp. & & & & & 2575 & 12.2 \\
\hline Brook stickleback & 142 & 1 & & & 22 & 0.1 \\
\hline Trout-perch $^{\mathrm{a}}$ & & & & & & \\
\hline Grand Total & 14463 & 100 & 490 & 100 & 21025 & 100 \\
\hline
\end{tabular}

a Note: Trout-perch have not been previously documented in the Milk River, but were present in 2000 .

In the Milk River, shorthead sculpin were distributed throughout the majority of the mainstem, however, they were generally absent from the lowermost sections (Figure 3.1). The results from the present study were consistent with those documented in 1986 (RL\&L) and other studies, with the exception of the upper Milk River (above its confluence with the North Milk River). Shorthead sculpins have been documented in the upper Milk River in previous years; during the present study, this section of river was dry.

Shorthead sculpin were present throughout the entire study section of the St. Mary River (above the reservoir) in 2000. However, in Lee Creek, shorthead sculpin were documented only in the lower sections (upper distribution was approximately $6 \mathrm{~km}$ upstream of Cardston).

\section{Stonecat}

In Canada, the stonecat occurs in the St. Lawrence River and tributaries, the Great Lakes area, southern Manitoba, and southern Alberta. Within Alberta, stonecats have been recorded only from the Milk River. The present study documented stonecats primarily in the mid-sections of the Milk River and at one site in the lower section (Figure 3.2). However, Willock (1969) documented a much broader range, where their distribution was recorded 
from the confluence with the North Milk River, downstream to the International Boundary Crossing.

\section{Western Silvery Minnow}

The western silvery minnow occurs in Canada in western Quebec, eastern Ontario, southern Manitoba, and southern Alberta. Within Alberta, this species is restricted to the Milk River, and possibly the South Saskatchewan River (RL\&L 1987). The western silvery minnow within the Milk River appeared to have a limited distribution in the 2000 and 1986 sampling by RL\&L (Figure 3.3). In these two studies, the silvery minnow was documented only in the lower Milk River. The most westerly site documented for the silvery minnow was located downstream of the town of Milk River (In: Nelson and Paetz 1992). Other authors that have documented the western silvery minnow in the Milk River include: Willock (1969) and Clayton and Ash (1980). Willock (1969) reported a substantial population of silvery minnows in the Lost River (a tributary to the Milk River); however, during the 2000 study, the Lost River at the Highway 502 bridge crossing was dry. Willock (1969) also noted that the Lost River is a small, intermittent stream, and thus not always available as habitat to the western silvery minnow.

One specimen of the western silvery minnow has previously been recorded in the South Saskatchewan River by Henderson and Peter (1969); however, the identification of this specimen has been questioned. Nelson and Paetz (1992) noted that the specimen should be obtained for species verification. Willock (1969) suggested that this specimen may have been captured for bait and released in the South Saskatchewan River.

\section{Brassy Minnow}

The brassy minnow occurs in Canada in the St. Lawrence River-Great Lakes area, and in southern Manitoba, Saskatchewan, Alberta, and isolated areas in British Columbia. In Alberta, the brassy minnow has been recorded only in the Milk River basin, Musreau Lake (Peace River drainage), and the Athabasca River near Fort McMurray (RL\&L 1987). The distribution of brassy minnow appeared to be limited to the mid-section of the Milk River, from the Town of Milk River downstream to the Aden Bridge (RL\&L 2001 and 1987; Figure 3.4). However, Nelson and Paetz (1992) noted a site in the lower Milk River near the International Boundary Crossing. Willock (1969) reported brassy minnow in a number of tributaries draining from the Sweetgrass and Cypress Hills area including Breed, Black and Police Coulee creeks; the author also noted that this species was not documented in Deer and Van Cleeve Coulee creeks. During the 2000 study, most tributaries were dry due to extreme drought conditions in the area.

\section{Sauger}

In Canada, sauger occurs in the St. Lawrence River-Great Lakes area, and in southern Manitoba, Saskatchewan, and Alberta. Within Alberta, this species occurs in the North Saskatchewan, Red Deer, Bow, Oldman, St. Mary, South Saskatchewan, and Milk rivers (Nelson and Paetz 1992). In the Milk River, sauger have been recorded from the confluence with the North Milk River, downstream to the International Boundary Crossing (Figure 3.5; Willock 1969; RL\&L 1987). 


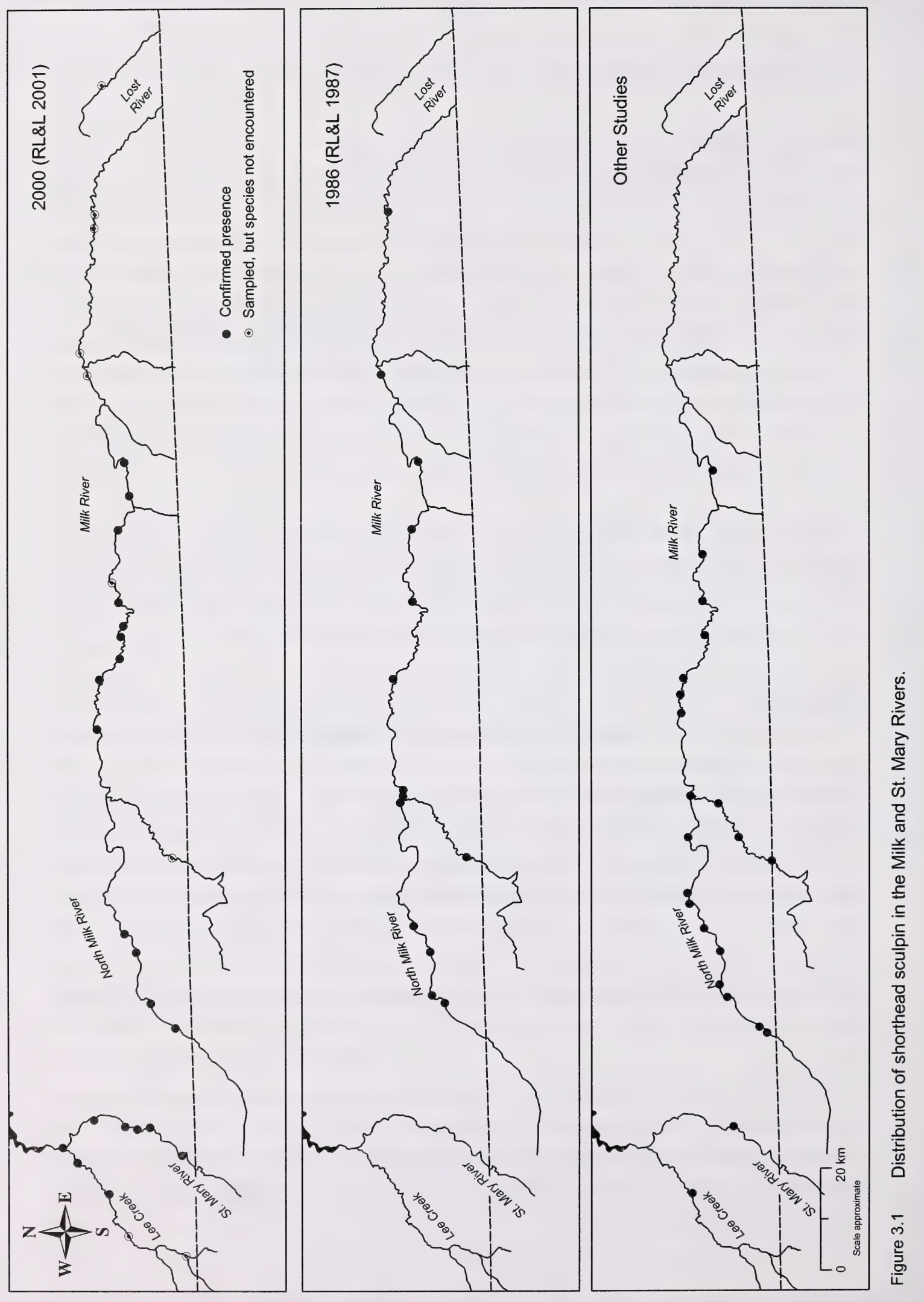




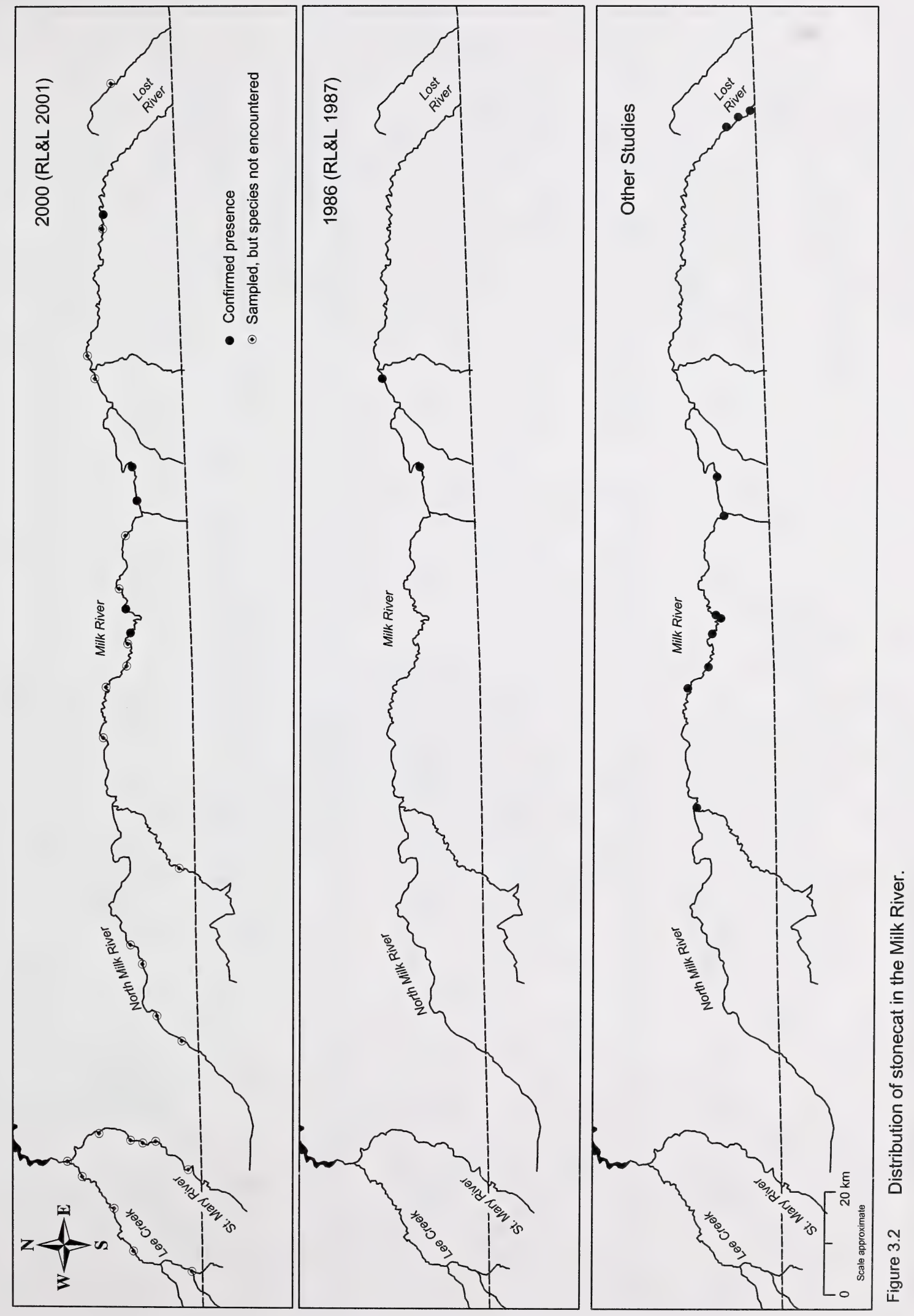




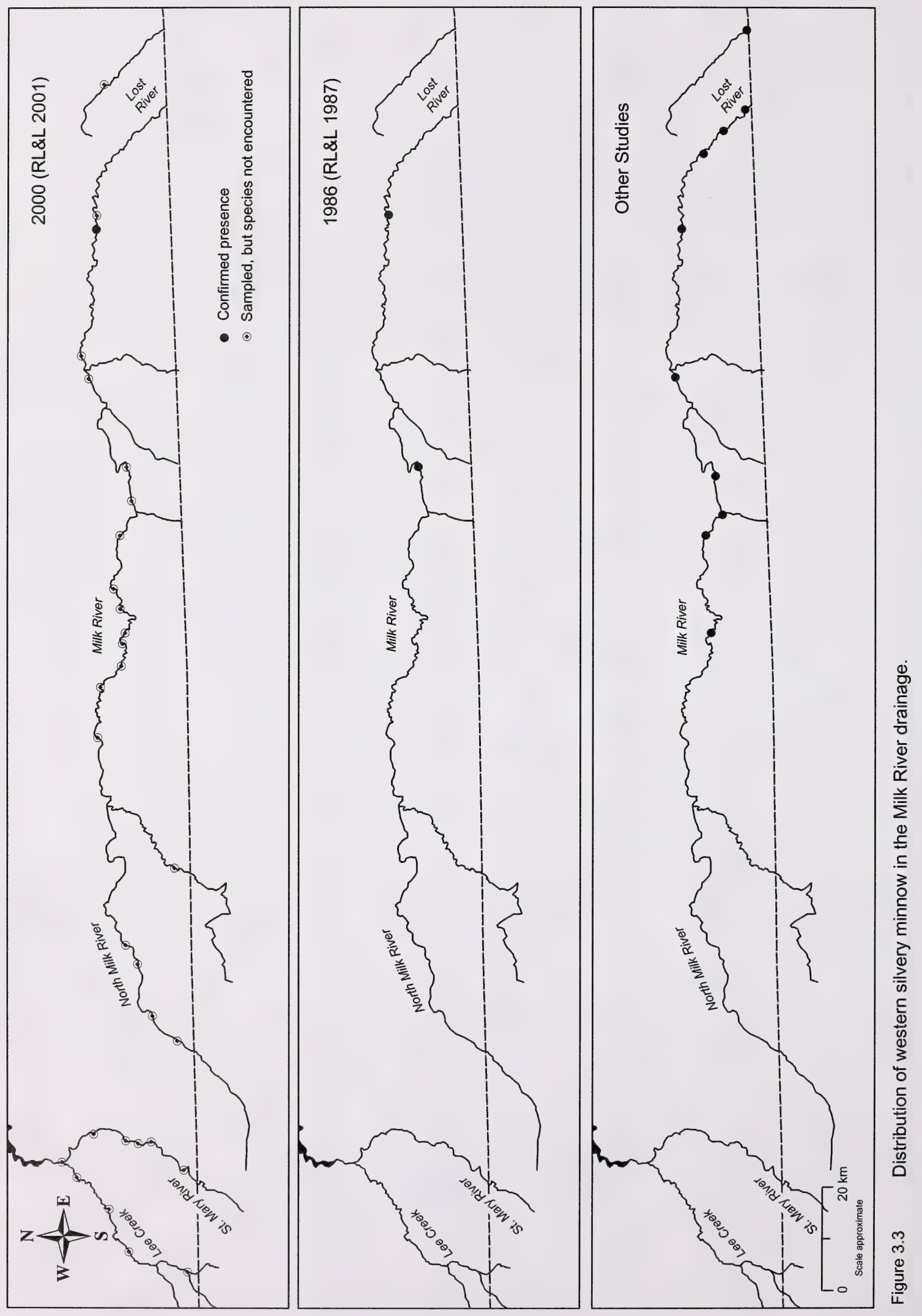




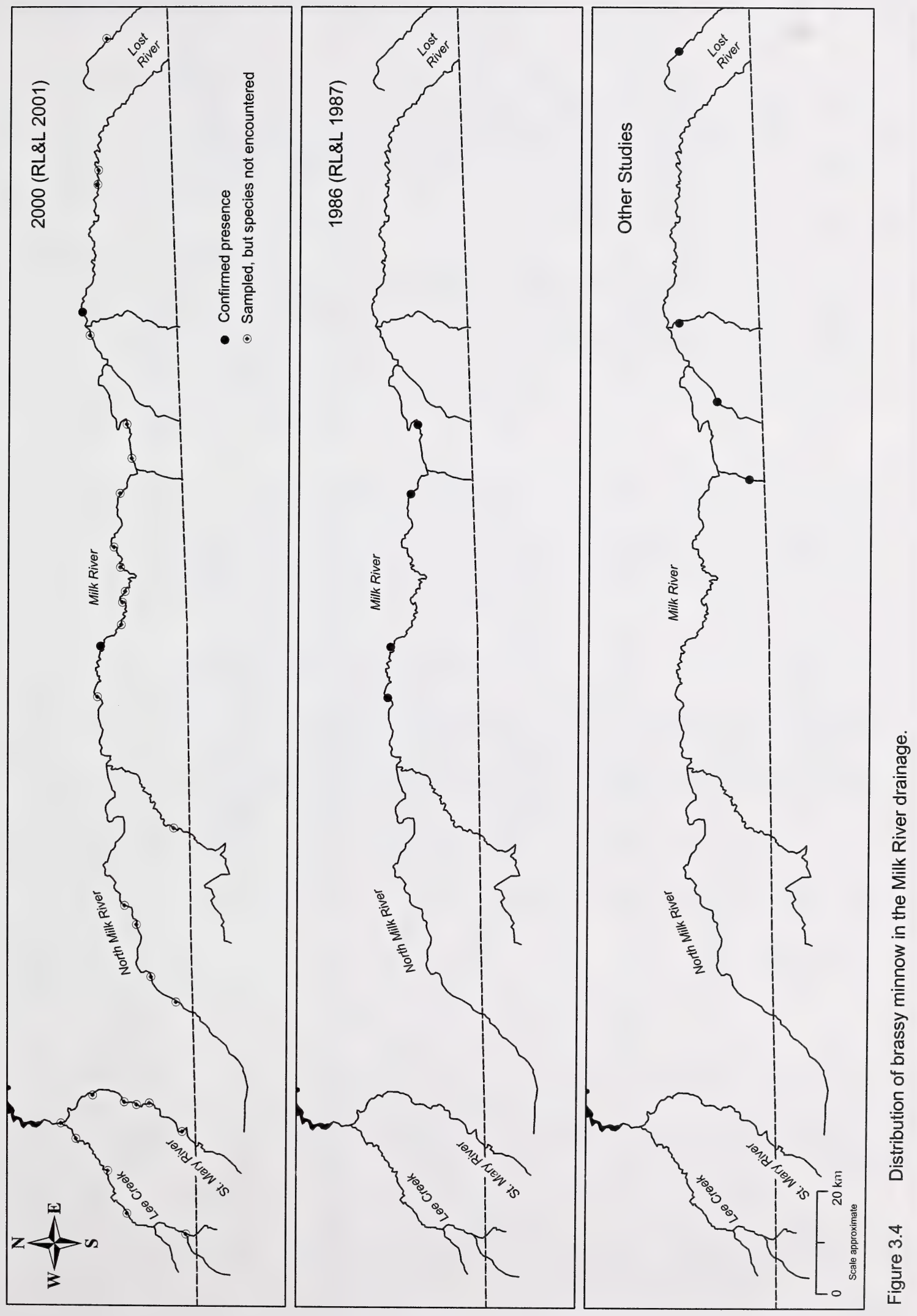




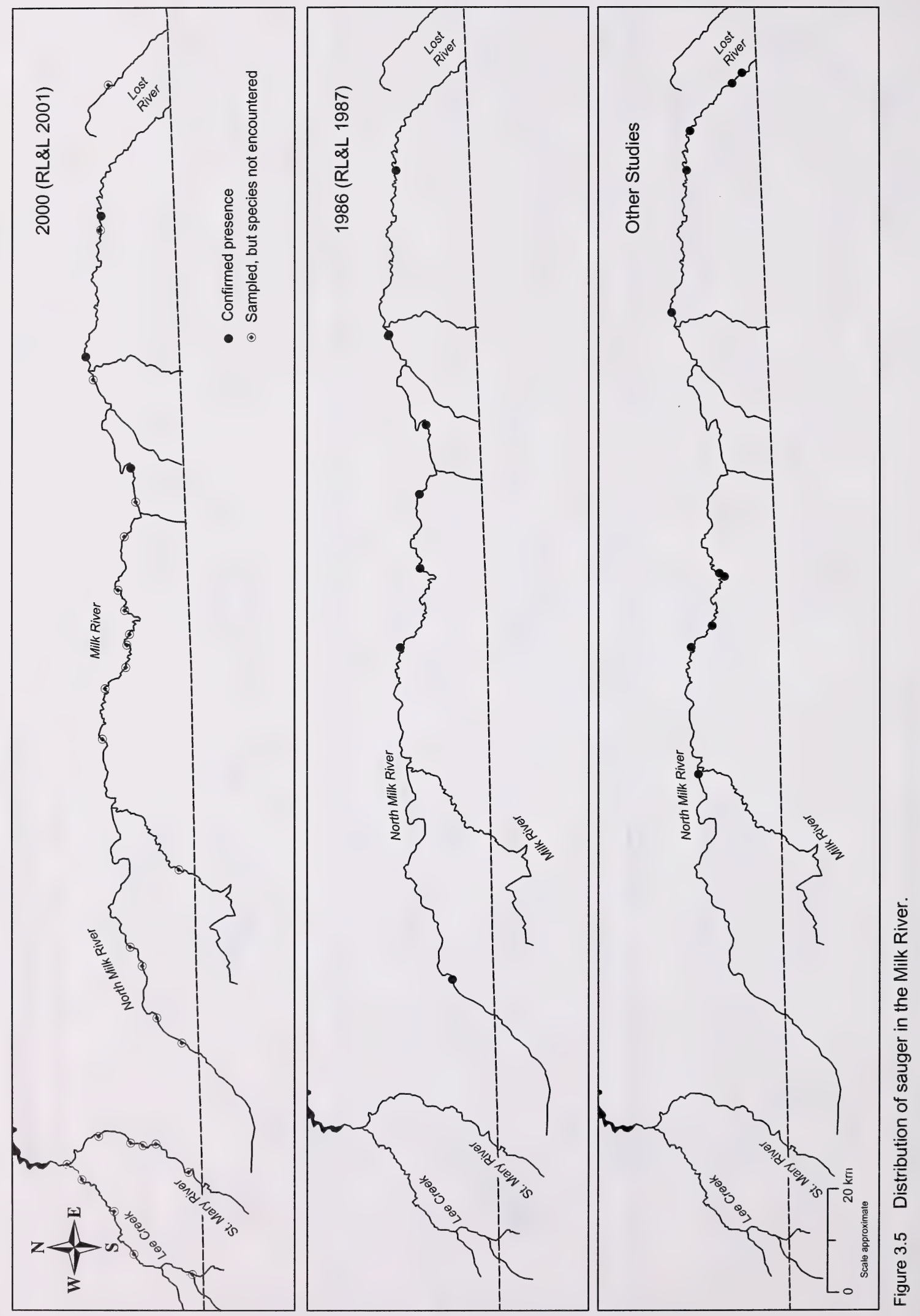




\subsubsection{Fish Abundance}

Backpack electrofishing and beach seines were the two main sampling methods used to calculate relative fish abundance. This section outlines the results for three categories: abundance by drainage, abundanceby site, and comparisons to historical data.

\section{Abundance by Drainage}

The relative abundance of most species varied seasonally. In the Milk River during summer, shorthead sculpin had the highest relative abundance $(0.7 \mathrm{fish} / \mathrm{min})$, while longnose dace were second in abundance $(0.5 \mathrm{fish} / \mathrm{min}$; Table 3.4). During fall, both longnose dace and shorthead sculpin had similar abundances ( 2.0 and 1.8 fish/min, respectively). In general, the relative abundance of most fish species in the Milk River was higher during fall than summer, with the exception of brassy minnow.

In contrast, longnose dace exhibited the highest relative abundance ( $7.5 \mathrm{fish} / \mathrm{min})$ in the St. Mary River during summer, followed by shorthead sculpin (2.4 fish/min; Table 3.4). During fall, the opposite was true; shorthead sculpin had the highest abundance ( $4.2 \mathrm{fish} / \mathrm{min}$ ), followed by longnose dace ( $2.0 \mathrm{fish} / \mathrm{min}$ ). Lee Creek was sampled only during summer, and longnose dace were by far the most abundant species ( $43.7 \mathrm{fish} / \mathrm{min})$ at this time.

Table 3.4 Seasonal relative abundances (no. fish/min) for species encountered by backpack electrofishing in the Milk and St. Mary drainages, 2000.

\begin{tabular}{|c|c|c|c|c|c|c|c|c|}
\hline \multirow{2}{*}{ Species } & \multirow[b]{2}{*}{ Effort } & \multicolumn{3}{|c|}{ Milk River } & \multicolumn{3}{|c|}{ St. Mary River } & \multirow{2}{*}{$\begin{array}{c}\text { Lee Creek } \\
\text { Summer } \\
(22 \mathrm{~min}) \\
\end{array}$} \\
\hline & & $\begin{array}{l}\text { Summer } \\
\text { (42 } \mathrm{min})\end{array}$ & $\begin{array}{c}\text { Fall } \\
(142 \mathrm{~min})\end{array}$ & $\begin{array}{l}\text { Overall } \\
\text { (184 min) }\end{array}$ & $\begin{array}{l}\text { Summer } \\
(36 \mathrm{~min})\end{array}$ & $\begin{array}{c}\text { Fall } \\
(14 \mathrm{~min}) \\
\end{array}$ & $\begin{array}{l}\text { Overall } \\
(49 \mathrm{~min}) \\
\end{array}$ & \\
\hline Brassy minnow & & 0.02 & & 0.01 & & & & \\
\hline Sauger & & & 0.13 & 0.10 & & & & \\
\hline Shorthead sculpin & & 0.65 & 1.83 & 1.56 & 2.42 & 4.15 & 2.89 & 1.53 \\
\hline Stonecat & & & 0.24 & 0.18 & & & & \\
\hline Burbot & & & 0.02 & 0.02 & & & & \\
\hline Cutthroat trout & & & & & & & & 0.14 \\
\hline Rainbow trout & & & & & & & & 0.09 \\
\hline Mountain whitefish & & & 0.01 & 0.01 & & & & \\
\hline Flathead chub & & 0.19 & 0.58 & 0.49 & & & & \\
\hline Lake chub & & & 0.04 & 0.03 & & & & 0.05 \\
\hline Longnose dace & & 0.48 & 2.00 & 1.66 & 7.46 & 2.00 & 5.97 & 43.73 \\
\hline Longnose sucker & & 0.07 & 0.38 & 0.31 & & & & \\
\hline Mountain sucker & & 0.05 & 0.17 & 0.14 & & 0.22 & 0.06 & 4.32 \\
\hline White sucker & & & 0.05 & 0.04 & & 0.15 & 0.04 & 0.05 \\
\hline Sucker spp. & & & 0.70 & 0.54 & 0.03 & 1.04 & 0.30 & 3.53 \\
\hline Trout-perch & & & 0.01 & 0.01 & 0.08 & 0.37 & 0.16 & \\
\hline Unidentified & & & & & 0.03 & & 0.02 & 0.05 \\
\hline Total & & 1.46 & 6.14 & 5.08 & 10.02 & 7.93 & 9.45 & 53.49 \\
\hline
\end{tabular}


According to the summer beach seining results in the Milk River, longnose dace had the highest relative abundance $\left(9.7 \mathrm{fish} / 100 \mathrm{~m}^{2}\right)$, followed by sucker species (all species combined $\left.=8.5 \mathrm{fish} / 100 \mathrm{~m}^{2}\right)$, and flathead chub $(0.8$; Table 3.5). During fall, flathead chub exhibited the highest abundance ( $\left.26.9 \mathrm{fish} / 100 \mathrm{~m}^{2}\right)$, followed by sucker species (10.5) and longnose dace (3.3). In the St. Mary River, only longnose dace and shorthead sculpin were captured by beach seine. Longnose dace had the highest abundance during both seasons (Table 3.5). Beach seining was not conducted in Lee Creek due to the coarse substrate present.

Table 3.5 Seasonal relative abundances (no. fish $/ 100 \mathrm{~m}^{2}$ ) for fish species captured by beach seining in the Milk and St. Mary drainages, 2000.

\begin{tabular}{|c|c|c|c|c|c|c|}
\hline \multirow[t]{2}{*}{ Species } & \multicolumn{3}{|c|}{ Milk River } & \multicolumn{3}{|c|}{ St. Mary River } \\
\hline & 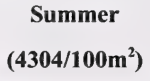 & $\begin{array}{c}\text { Fall } \\
\left(3480 / 100 \mathrm{~m}^{2}\right)\end{array}$ & 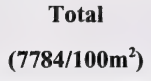 & 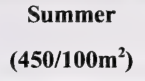 & $\begin{array}{c}\text { Fall } \\
\left(300 / 100 \mathrm{~m}^{2}\right)\end{array}$ & 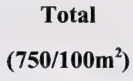 \\
\hline Brassy minnow & & 0.23 & 0.1 & & & \\
\hline Sauger & 0.02 & & 0.01 & & & \\
\hline Shorthead sculpin & 0.26 & 0.46 & 0.35 & 0.22 & 0.33 & 0.27 \\
\hline Western silvery minnow & & 0.06 & 0.03 & & & \\
\hline Burbot & 0.02 & & 0.01 & & & \\
\hline Flathead chub & 0.84 & 26.93 & 12.50 & & & \\
\hline Lake chub & 0.09 & 0.34 & 0.21 & & & \\
\hline Longnose dace & 9.69 & 3.28 & 6.82 & 5.78 & 0.67 & 3.73 \\
\hline Longnose sucker & 0.49 & 0.26 & 0.39 & & & \\
\hline Mountain sucker & 0.16 & 0.09 & 0.13 & & & \\
\hline Sucker spp. & 7.85 & 10.17 & 8.89 & & & \\
\hline Unidentified & & 0.03 & 0.01 & & & \\
\hline White sucker & & 0.09 & 0.04 & & & \\
\hline Grand Total & 19.42 & 41.93 & 29.48 & 6.00 & 1.00 & 4 \\
\hline
\end{tabular}

\section{Abundance by Site}

\section{Backpack electrofishing}

\section{Shorthead Sculpin}

In the Milk River, a total of ten sites were sampled during summer. Of those, shorthead sculpin were captured at four sites. However, during fall a total of 18 sites were sampled, and shorthead sculpin were encountered at 13 of those sites. During summer, the catch-per-unit-effort (CPUE) of the shorthead sculpins was highest in the North Milk River (Sites 7 to 10; Figure 3.6). During fall, shorthead sculpin were more widely distributed throughout the Milk River. However, similar to the summer results, their abundance was highest in the North Milk River and then decreased steadily in the downstream section (Figure 3.6). 

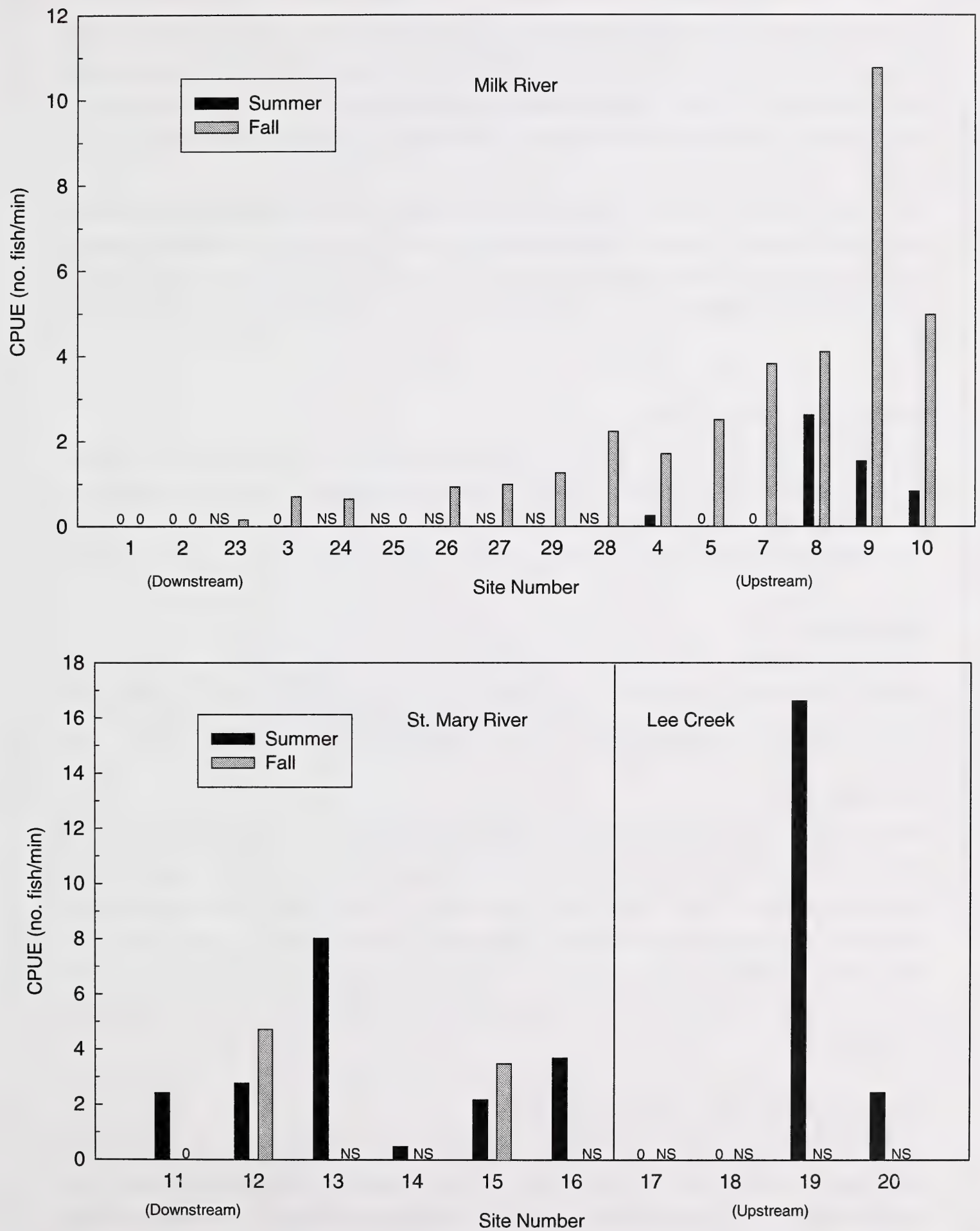

Figure 3.6 Relative abundance (no. fish/min) of shorthead sculpin captured using backpack electrofishing in the Milk and St. Mary drainages, 2000 (NS indicates Not Sampled). 
In the St. Mary River, a total of six sites were sampled during summer and two sites during fall. Shorthead sculpin were captured at all sites during both seasons. No trends in relative abundance were apparent throughout the sections sampled (Figure 3.6). The relative abundance of this species ranged from $0.5 \mathrm{fish} / \mathrm{min}$ at Site 14 to $8.0 \mathrm{fish} / \mathrm{min}$ at Site 13. Of the two sites sampled during both seasons, the abundance of shorthead sculpin was greater during fall.

In Lee Creek, a total of four sites were sampled during summer and no sites were sampled during fall. Shorthead sculpin were captured only at the two downstream sites (Sites 19 and 20; Figure 3.6). The abundance of shorthead sculpin in Lee Creek varied considerably between the two sites ( $2.5 \mathrm{vs} 16.6 \mathrm{fish} / \mathrm{min}$ ). The abundance of $16.6 \mathrm{fish} / \mathrm{min}$ at Site 19 was the highest recorded value for any of the Species of Concern throughout the entire study area.

\section{Stonecat, Sauger, and Brassy Minnow}

Stonecat were recorded near the Town of Milk River to the farthest downstream site (Site 1; Figure 3.7). Abundance of stonecat ranged from 0.2 to $1.5 \mathrm{fish} / \mathrm{min}$. Similarly, sauger were primarily found in the downstream reaches of the Milk River (Sites 2 and 23). The highest abundance of sauger in the Milk River was $3.5 \mathrm{fish} / \mathrm{min}$. During electrofishing surveys, the brassy minnow was captured only at Site 4 and their abundance was low ( $0.1 \mathrm{fish} / \mathrm{min})$.

\section{Beach seining}

All Species of Concern except stonecats were captured using beach seines (Table 3.6). Beach seining was the most effective sample method in the Milk River, particularly in the downstream sections during summer due to the substrate composition (i.e., sand) and high turbidity. Turbidity levels were considerably lower during fall.

\section{Shorthead Sculpin}

During summer, shorthead sculpin were only captured in the three upper North Milk River sites (Sites 7 to 9), with CPUE values ranging from 0.5 to $3.3 \mathrm{fish} / 100 \mathrm{~m}^{2}$ (Table 3.6). During fall, shorthead sculpin were only captured in the mid-section at Sites 3, 4 and 5; CPUE values ranged from 1.3 to $6.7 \mathrm{fish} / 100 \mathrm{~m}^{2}$. Due to the very low flows during fall and large substrate, beach seining was not conducted in the North Milk River. In the St. Mary River, beach seining was difficult due to the large substrate; however, beach seining was possible at Sites 12 and 15 . Shorthead sculpin were captured at Site 15 during summer $\left(0.7 \mathrm{fish} / 100 \mathrm{~m}^{2}\right)$ and at Site 12 during fall $\left(0.7 \mathrm{fish} / 100 \mathrm{~m}^{2}\right)$.

\section{Sauger, Western Silvery Minnow and Brassy Minnow}

Sauger was the only species captured during summer using beach seines. This species was captured in the most downstream site of the Milk River (Site 1) and was present in low abundance $\left(0.7 \mathrm{fish} / 100 \mathrm{~m}^{2}\right)$. During fall, western silvery and brassy minnows were captured using beach seines. Both species were found in the downstream sections of the Milk River. The abundance of the western silvery minnow was $1.2 \mathrm{fish} / 100 \mathrm{~m}^{2}$ (Site 21), while the brassy minnow abundance was $5.3 \mathrm{fish} / 100 \mathrm{~m}^{2}$ (Site 22; Table 3.6). 


In the St. Mary River and Lee Creek, the relative abundances of shorthead sculpin during summer were compared with data collected by Paetz (1993). These data were collected at the same locations between the two years of studies. In general, the abundance of shorthead sculpin varied between years (Figure 3.8). In 2000, abundances in the St. Mary River at Kimball Fairground were $2.77 \mathrm{fish} / \mathrm{min}$, while values reported by Paetz (1993) was 5.76 fish/min. In Lee Creek at the Cardston water intake, Paetz (1993) reported shorthead sculpin abundances of $3.60 \mathrm{fish} / \mathrm{min}$, while values in 2000 were $16.6 \mathrm{fish} / \mathrm{min}$.

In the Milk River system, Paetz (1993) recorded higher abundances of shorthead sculpin during summer than in 2000. In the North Milk River (Site 10), Paetz (1993) recorded abundances of 4.56 fish/min, while in 2000 values of $0.83 \mathrm{fish} / \mathrm{min}$ were recorded. At the Town of Milk River (Site 4), Paetz (1993) recorded abundances of $3.0 \mathrm{fish} / \mathrm{min}$, while in 2000 , values of $0.26 \mathrm{fish} / \mathrm{min}$ were recorded. However, similar to the present study, sampling conducted by Stantec (2000) at the Town of Milk River during August (one week prior to the present study), recorded abundances of 0.32 shorthead sculpin $/ \mathrm{min}$.

\section{Stonecat}

Relative abundance values of stonecat were much higher in 2000 than in 1986. In 2000, values ranged from 0.44 to $1.49 \mathrm{fish} / \mathrm{min}$, while in 1986 values were $0.09 \mathrm{fish} / \mathrm{min}$ at both capture sites (Figure 3.10). The capture results also indicate that there was a broader distribution of stonecat in 2000 relative to 1986.

\section{Western Silvery Minnow}

Western silvery minnow exhibited a limited distribution during both the 2000 and 1986 field sampling programs. This species was encountered at Site 21 (Pinhorn Ranch) in both years and farther upstream at the Deer Creek Bridge in 1986. The only data available to compare relative abundance between years was fall beach seine results; in 2000, a CPUE of $1.22 \mathrm{fish} / 100 \mathrm{~m}^{2}$ was recorded compared to $0.57 \mathrm{fish} / 100 \mathrm{~m}^{2}$ in 1986 (Figure 3.11 ).

\section{Brassy Minnow}

Similar to the western silvery minnow, the brassy minnow also displayed a limited distribution during the 2000 and 1986 field sampling programs. In both years, brassy minnows were restricted to the mid-section of the river. At the two lowermost sites within the mid-section, the beach seine CPUE of brassy minnow was higher in 2000 (5.33 fish $/ 100 \mathrm{~m}^{2}$ in October) than in 1986 (1.33 and $0.33 \mathrm{fish} / 100 \mathrm{~m}^{2}$ in July and August, respectively). Backpack electrofishing CPUE was similar between 1986 and 2000 ( $<0.1 \mathrm{fish} / \mathrm{min}$; Figure 3.12).

\section{Sauger}

Since few sauger were captured during August 2000 and few were captured during October 1986, results from both periods were presented, as well as a study by Stantec in 2000. All studies indicated that the abundances of sauger were low ( $<0.2 \mathrm{fish} / \mathrm{min}$ ), with the exception of Site 2 during fall 2000 (CPUE of $3.46 \mathrm{fish} / \mathrm{min}$; Figure 3.13 ). 

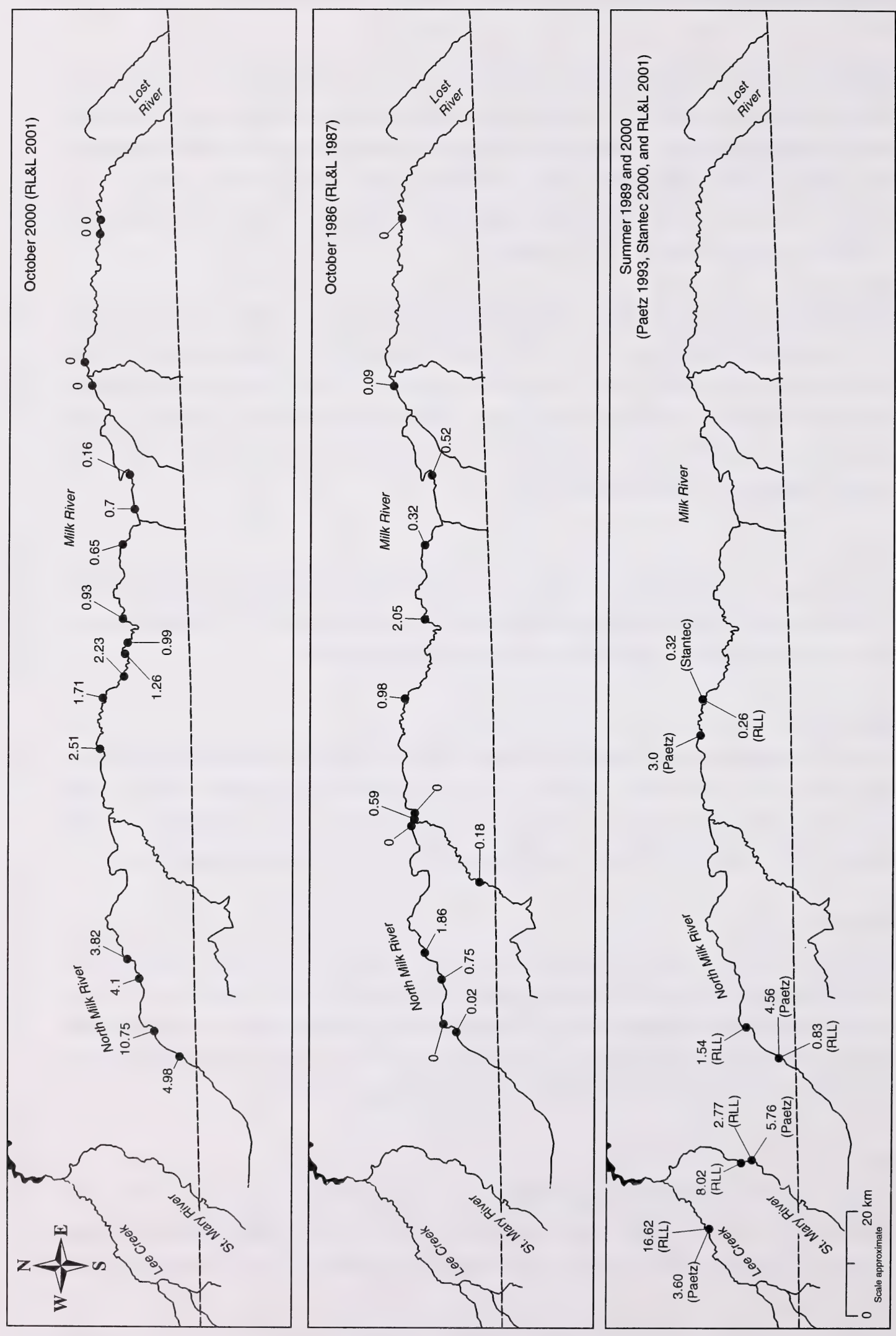

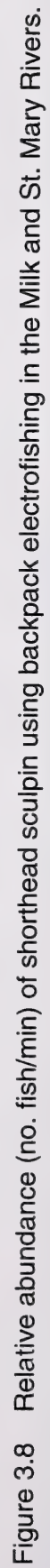



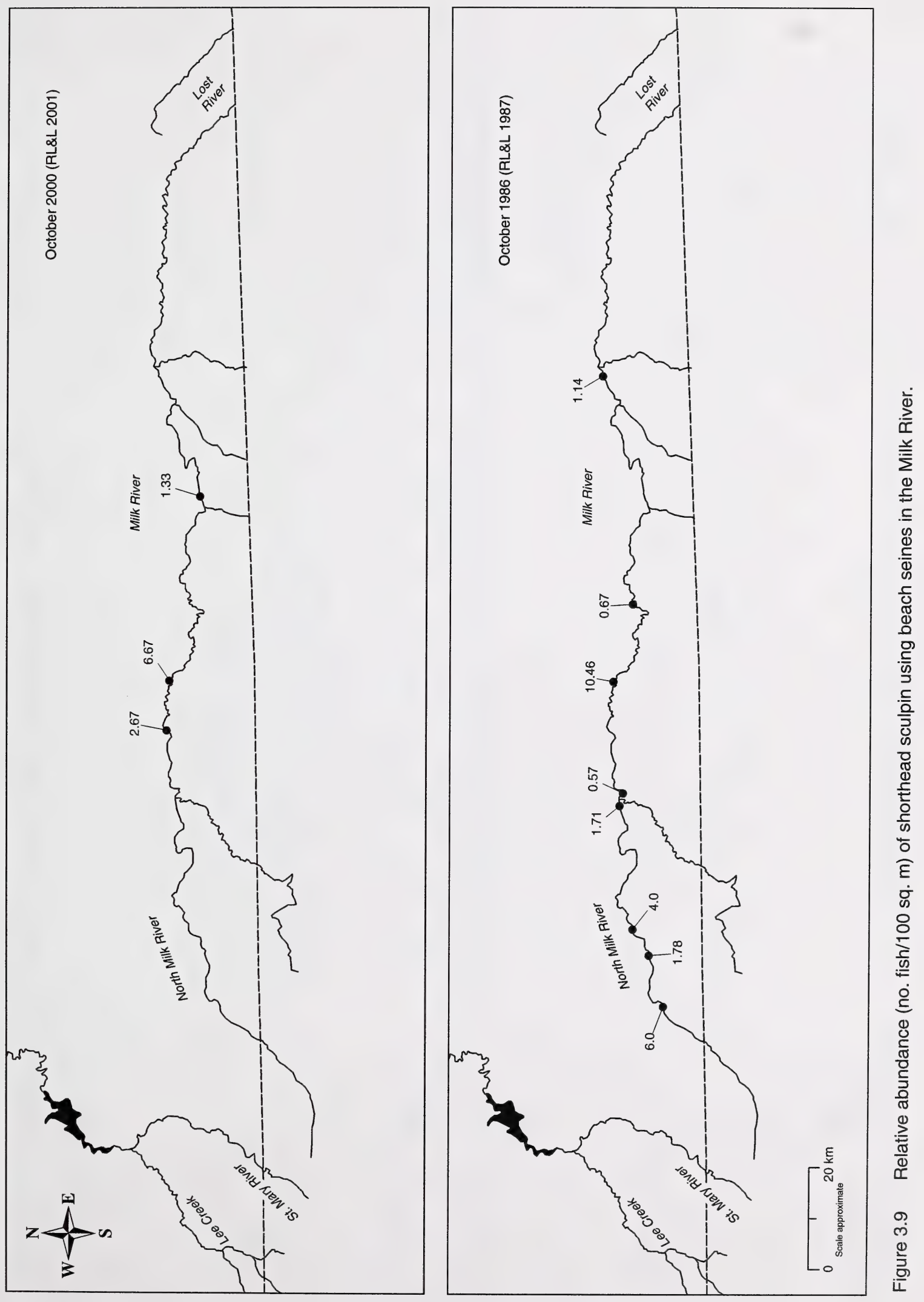

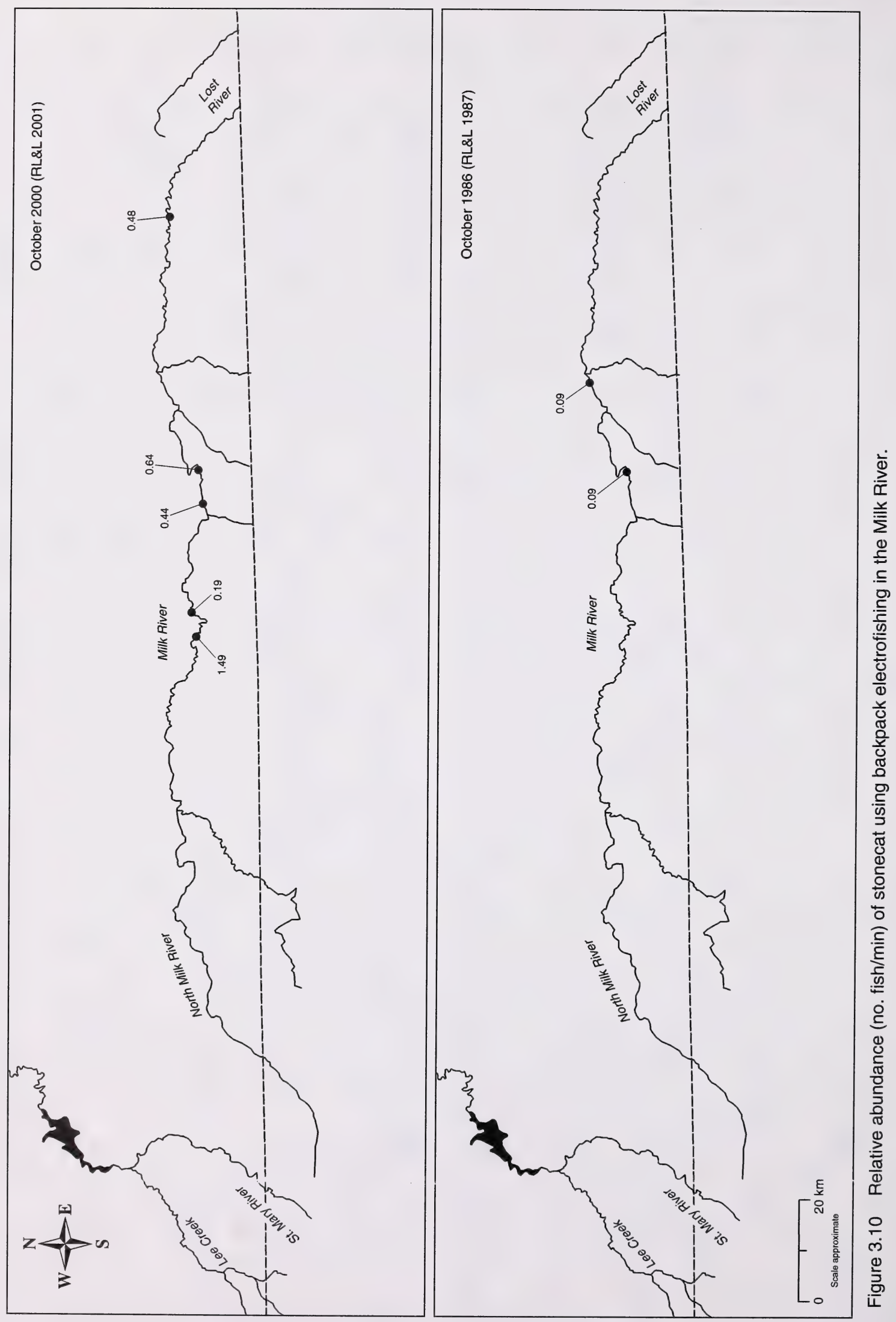


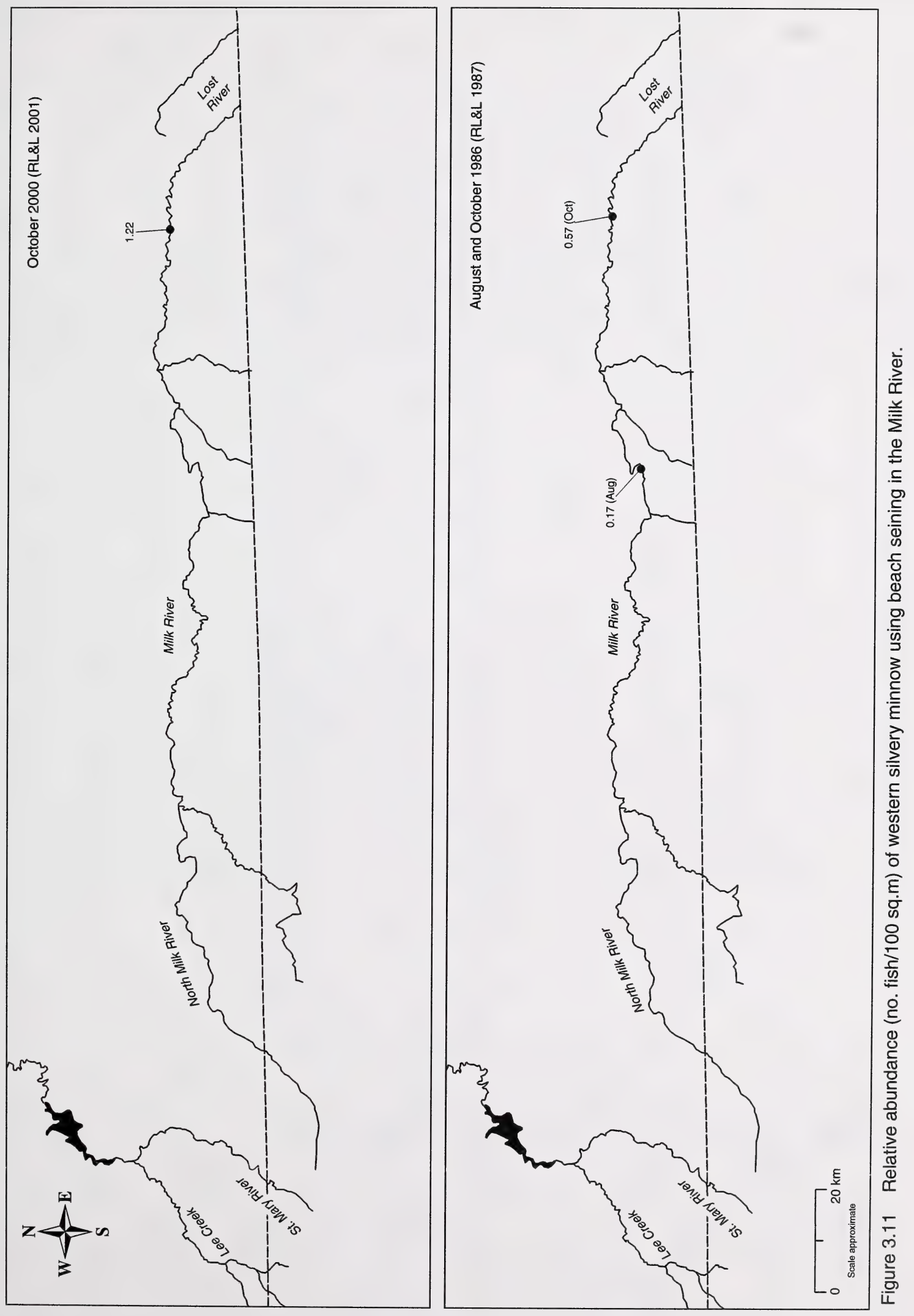




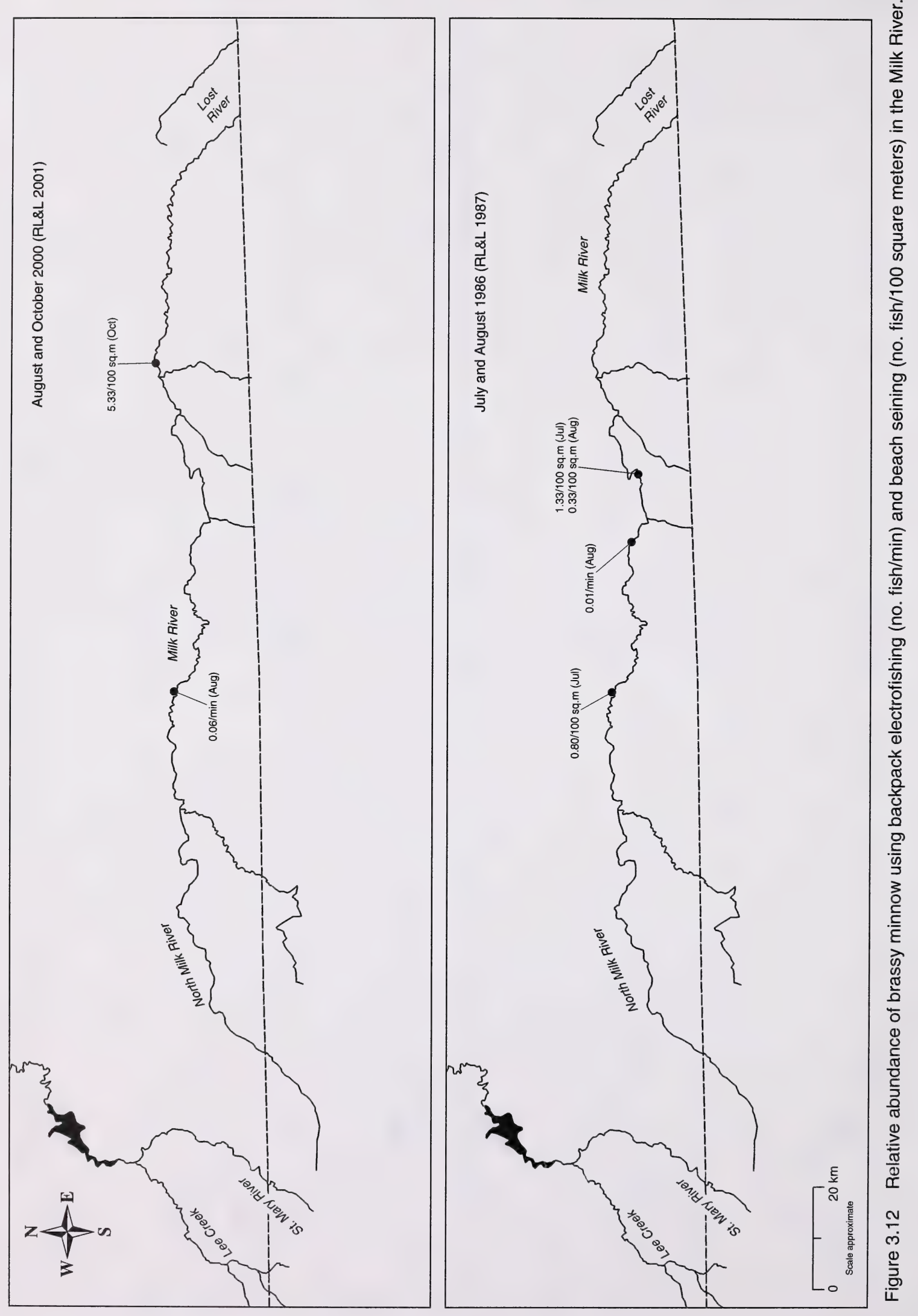




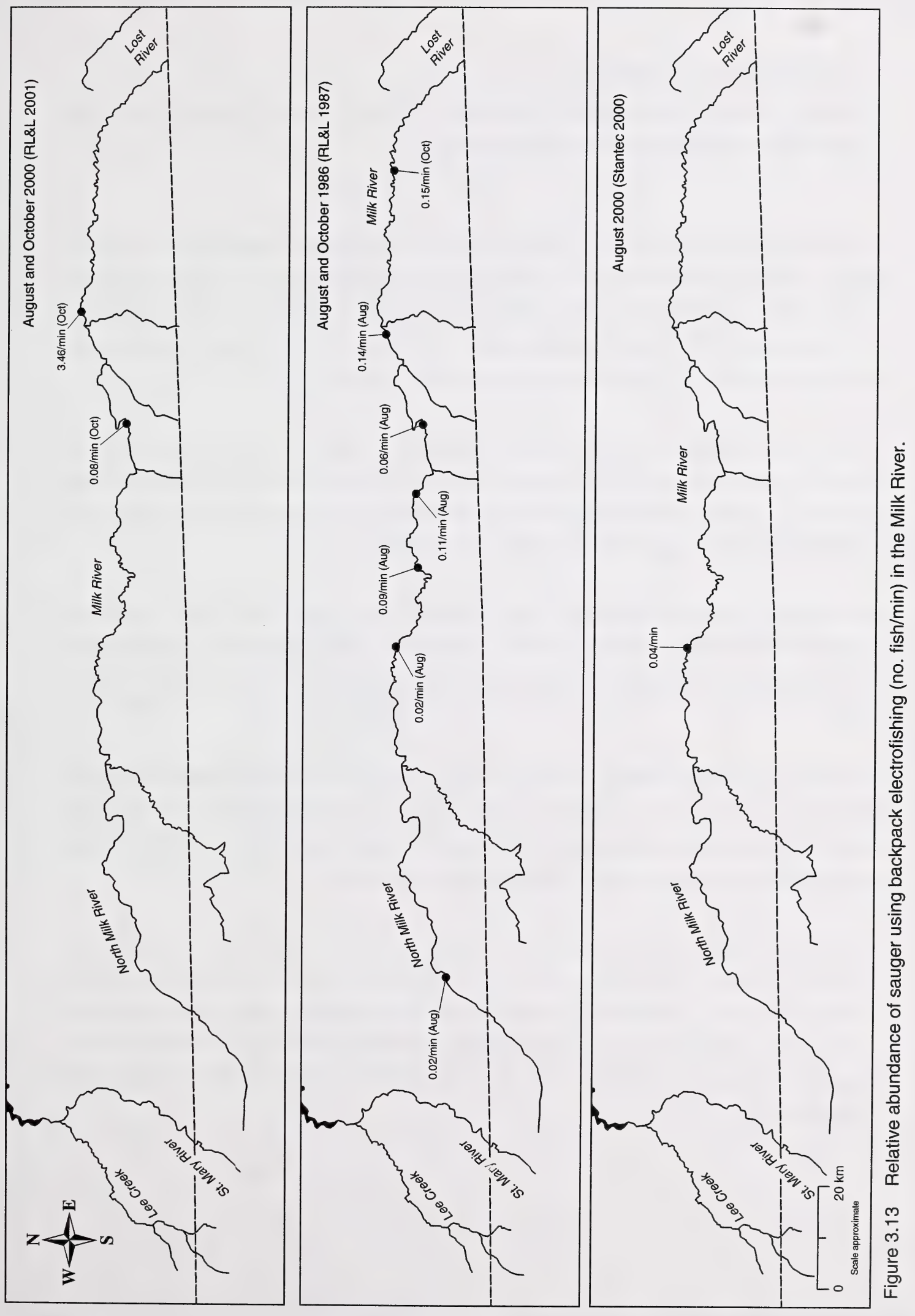




\subsubsection{Life History Characteristics}

This section provides descriptive statistics of fork length by site for the Species of Concern and statistical comparisons of fork length to assess reach differences in length.

Shorthead sculpin in the Milk River had mean fork lengths (at a given site) that ranged from 46 to $79 \mathrm{~mm}$. The minimum fork length of shorthead sculpin was $19 \mathrm{~mm}$, while the maximum fork length was $114 \mathrm{~mm}$. In the St. Mary River, mean fork lengths (by site) ranged from 25 to $58 \mathrm{~mm}$, with a minimum of $19 \mathrm{~mm}$ and a maximum of $99 \mathrm{~mm}$. In Lee Creek, the mean fork length of shorthead sculpin was $40 \mathrm{~mm}$ at each of the two sites; the minimum fork length of individual fish in Lee Creek was $26 \mathrm{~mm}$ and maximums were $76 \mathrm{~mm}$.

Length frequency histograms of shorthead sculpin for the Milk and St. Mary rivers and Lee Creek are presented in Figure 3.14. Shorthead sculpin exhibited a unimodal distribution in all three drainages. In the Milk and St. Mary rivers, the 50 - $59 \mathrm{~mm}$ length category represented the highest frequency. In Lee Creek, shorthead sculpin were generally smaller (highest length frequency category was the $30-39 \mathrm{~mm}$ ).

Age-at-maturity has been documented at 2+ years (Roberts 1988). In the St. Mary River, Roberts (1988) documented that the smallest mature female was $52.3 \mathrm{~mm}$ total length, while the largest mature female was $80 \mathrm{~mm}$. The maximum length of shorthead sculpin documented from the Milk River was $108 \mathrm{~mm}$ total length (Roberts 1988).

Stonecats were captured at five sites in the Milk River, with the mean fork lengths at individual sites ranging from 88 to $246 \mathrm{~mm}$. Western silvery minnow were captured at one site and the mean fork length of the sample was $41 \mathrm{~mm}$. Brassy minnow were captured at two sites; the mean fork lengths at each site were 26 and $48 \mathrm{~mm}$. Sauger were captured at three sites, where fork lengths ranged from 343 to $405 \mathrm{~mm}$.

A one-way ANOVA was performed to determine if site differences in length existed for the Species of Concern. This analysis could not be performed on western silvery minnow since this species was captured only at one site. Results of the ANOVA indicate that there were significant differences in fork length between sites for brassy minnow, stonecats, and shorthead sculpin in the Milk River, and shorthead sculpin in the St. Mary River $(\mathrm{P}<0.05)$. No significant differences in fork length between sites were documented for sauger in the Milk River and shorthead sculpin in Lee Creek. 
For shorthead sculpin in the Milk River, Site 9 contributed primarily to the significant results (this site was only significantly different from Sites 3, 7, and 28; Table 3.7); all other sites were not significantly different. Site 9 had the lowest mean fork length of all the sites analysed $(46 \mathrm{~mm})$. In the St. Mary River, there were essentially two groupings of sites for shorthead sculpin that did not exhibit significantly different fork lengths. The first grouping was Sites 12, 13, and 15, which had mean fork lengths of $>50 \mathrm{~mm}$, while the second grouping was Sites 14 and 16, which had mean fork lengths of $<40 \mathrm{~mm}$ (Table 3.7). In the Milk River, brassy minnow were smaller in the downstream site (Site 22) than the upstream site (Site 4; Table 3.7). For stonecats, Site 1 contributed primarily to the significant results. Stonecats at this site had the highest mean fork length $(246 \mathrm{~mm})$.

Table 3.7 Length differences between sample sites for the Species of Concern in the Milk and St. Mary rivers using a one-way ANOVA (Significance level was $\mathrm{P}<0.05$ ).

\begin{tabular}{|c|c|c|c|c|c|c|c|c|c|c|c|c|c|c|c|}
\hline Waterbody & Species & Parameter & \multicolumn{11}{|c|}{ (Downstream) } & \multicolumn{2}{|c|}{ (Upstream) } \\
\hline \multirow[t]{3}{*}{ Milk River } & Shorthead & Site No. & 23 & 3 & 24 & 26 & 27 & 29 & 28 & 4 & 5 & 7 & 8 & 9 & 10 \\
\hline & & Significance & $\mathrm{AB}$ & $\mathrm{A}$ & $\mathrm{AB}$ & $\mathrm{AB}$ & $\mathrm{AB}$ & $\mathrm{AB}$ & A & $\mathrm{AB}$ & $\mathrm{AB}$ & $\mathrm{A}$ & $\mathrm{AB}$ & B & $\mathrm{AB}$ \\
\hline & & Mean FL & 71 & 61 & 58 & 53 & 79 & 70 & 76 & 56 & 57 & 61 & 50 & 46 & 56 \\
\hline \multirow[t]{3}{*}{ St. Mary River } & Shorthead & Site No. & 16 & 15 & 14 & 13 & 12 & 11 & & & & & & & \\
\hline & & Significance & $\mathbf{A}$ & B & $\mathbf{A}$ & B & B & $\mathrm{AB}$ & & & & & & & \\
\hline & & Mean FL & 39 & 57 & 25 & 58 & 53 & 39 & & & & & & & \\
\hline \multirow[t]{3}{*}{ Milk River } & Brassy Minnow & Site No. & 22 & 4 & & & & & & & & & & & \\
\hline & & Significance & A & B & & & & & & & & & & & \\
\hline & & Mean FL & 29 & 48 & & & & & & & & & & & \\
\hline \multirow[t]{3}{*}{ Milk River } & Stonecat & Site No. & 1 & 23 & 3 & 26 & 27 & & & & & & & & \\
\hline & & Significance & $\mathbf{A}$ & B & $\mathrm{AB}$ & $\mathrm{AB}$ & B & & & & & & & & \\
\hline & & Mean FL & 246 & 118 & 88 & 165 & 99 & & & & & & & & \\
\hline
\end{tabular}

\subsection{HABITAT}

\subsubsection{Physical and Chemical Characteristics}

A range of physical and chemical characteristics were measured in the Milk and St. Mary drainages during the 2000 field program (Table 3.8). Parameters included water temperature, conductivity, $\mathrm{pH}$, turbidity, dissolved oxygen, and discharge. As expected water temperature, discharge, and urbidity were lower during the fall survey. Dissolved oxygen was higher during fall ( $2.4 \mathrm{mg} / \mathrm{L}$ higher) and $\mathrm{pH}$ was similar between seasons.

Water temperatures were generally similar between sites; however, the lower Milk River (Site 2) exhibited slightly warmer water temperatures during the sample period (Figure 3.15).

Historical discharge data was reviewed for three periods (August representing the summer sampling period, October representing the fall sampling period, and December representing critical overwintering periods; Figure 3.16). The 
mean monthly discharge for August 2000 was $13.8 \mathrm{~m}^{3} / \mathrm{s}$, which was similar to the historical mean discharge of $14.6 \mathrm{~m}^{3} / \mathrm{s}$. However, during October and December 2000, discharge values were well below mean historical discharges. In October 2000, the mean monthly discharge was $0.3 \mathrm{~m}^{3} / \mathrm{s}$, compared to the mean historical discharge of $2.7 \mathrm{~m}^{3} / \mathrm{s}$. In December 2000 , the mean monthly discharge was $0.2 \mathrm{~m}^{3} / \mathrm{s}$, compared to the mean historical discharge of $1.0 \mathrm{~m}^{3} / \mathrm{s}$.

Table 3.8 Summary of physical and chemical characteristics in the Milk and St. Mary drainages, August and October, 2000.

\begin{tabular}{|c|c|c|c|c|c|}
\hline Season & Parameter & $\mathbf{N}$ & Mean & Minimum & Maximum \\
\hline \multirow[t]{6}{*}{ August } & Temperature $\left({ }^{\circ} \mathrm{C}\right)$ & 19 & 20.3 & 16.3 & 26.5 \\
\hline & Conductivity $(\mu \mathrm{S})$ & 19 & 176 & 100 & 420.0 \\
\hline & $\mathrm{pH}$ & 19 & 8.5 & 6.5 & 8.9 \\
\hline & Turbidity (NTU) & 19 & 8.3 & 0.7 & 52.7 \\
\hline & Dissolved Oxygen (mg/L) & 19 & 8.6 & 7.4 & 11.4 \\
\hline & Discharge $^{a}\left(\mathrm{~m}^{3} / \mathrm{s}\right)$ & 19 & 14.11 & 13.81 & 14.38 \\
\hline \multirow[t]{6}{*}{ October } & Temperature $\left({ }^{\circ} \mathrm{C}\right)$ & 20 & 7.3 & 2.1 & 11.0 \\
\hline & Conductivity $(\mu S)$ & 20 & 391.5 & 110.0 & 570.0 \\
\hline & $\mathrm{pH}$ & 18 & 8.4 & 6.2 & 8.8 \\
\hline & Turbidity (NTU) & 20 & 1.8 & 1.1 & 3.3 \\
\hline & Dissolved Oxygen (mg/L) & 19 & 11.0 & 9.5 & 12.1 \\
\hline & $\operatorname{Discharge}^{\mathrm{a}}\left(\mathrm{m}^{3} / \mathrm{s}\right)$ & 20 & 0.26 & 0.24 & 0.31 \\
\hline
\end{tabular}

Discharge values from the Milk River at the Town of Milk River.

\subsubsection{Habitat Use and Requirements}

The following section describes habitat use of the Species of Concern from literature reviews and data collected during the present study.

\subsubsection{Shorthead sculpin}

Very little is known about the habitat requirements of the shorthead sculpin (Scott and Crossman 1973; Nelson and Paetz 1992), particularly those occurring in Alberta. Shorthead sculpin generally inhabit riffles of small, cold streams (Scott and Crossman 1973; Lee et al. 1980 from Peden and Hughes 1984). Peden and Hughes (1984) determined that shorthead sculpin in the Flathead River, British Columbia were most abundant in areas of slow current and rocky bottoms; however, it was documented that sculpins were not always associated with riffle habitats. The authors also indicated that shorthead sculpin were generally located in areas that were not heavily sedimented. Similarly, RL\&L (1987) recorded that sculpin were abundant in the North Milk and upper Milk rivers, in areas of large gravel and cobble, with relatively low silt deposition. 


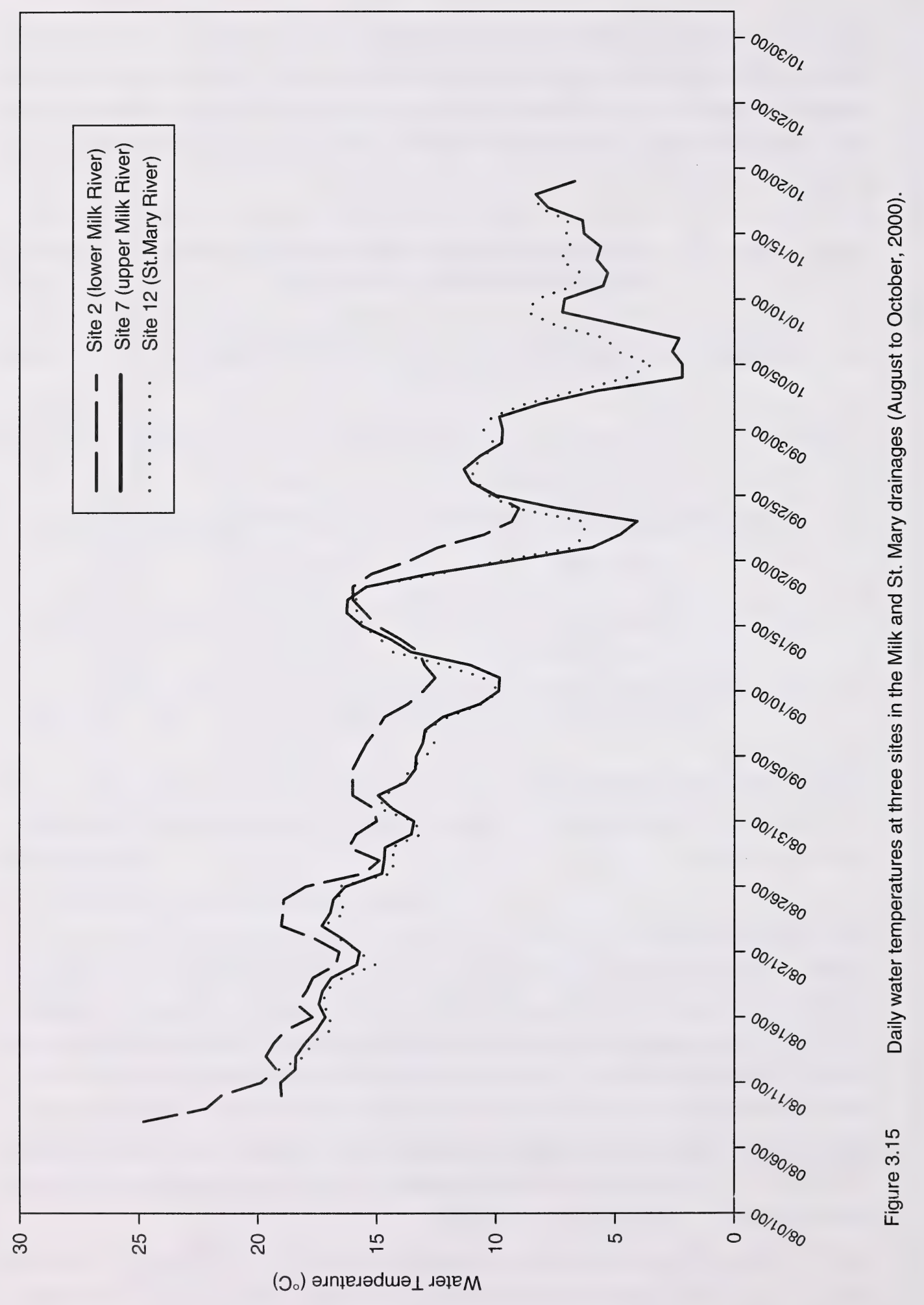



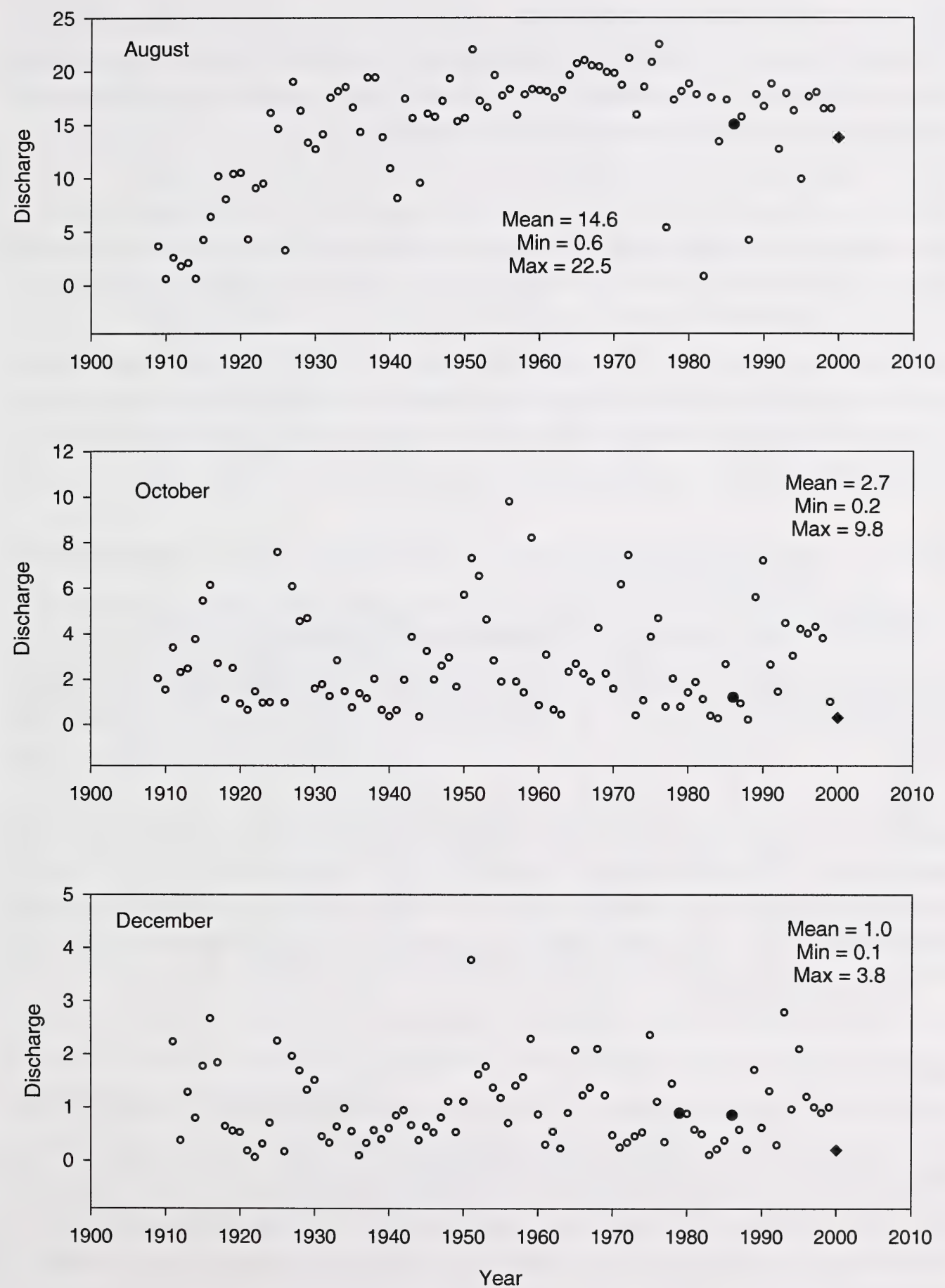

Figure 3.16 Historical discharge for August, October, and December in the Milk River at the Town of Milk River (closed symbols represent discharges in 1979, 1986, and 2000). 
Spawning is presumed to occur in May or June. Eggs are deposited on or under rocks. Males have been observed guarding and fanning the nest (Lee et al. 1980 from Peden and Hughes 1984; Roberts 1988). Shorthead sculpin feed primarily on aquatic insects (Peden and Hughes 1984; Roberts 1988). It is believed that juveniles and adults of this species do not undertake extensive migrations (Peden and Hughes 1984).

\section{Habitat Types}

In the present study, shorthead sculpin were captured predominantly in riffles $(48 \%$ occurrence in areas where sculpin were captured) and shallow runs (32\%; Table 3.9). However, differences in habitat types between the three drainages were evident. In the Milk River, shorthead sculpin utilized a diverse range of habitat types. Most individuals were associated with shallow runs (R3; 39\%), followed by riffle (27\%), and riffle/boulder gardens (16\%). Shorthead sculpin were also present in backwaters, shallow flats, and pool habitat types. In the St. Mary River and Lee Creek, shorthead sculpin were associated with both riffles and shallow runs, but riffles were by far the dominant habitat type ( $>74 \%$ occurrence).

Table 3.9 Percent occurrence of habitat types ${ }^{\mathrm{a}}$ in areas where shorthead sculpin were captured in the Milk and St. Mary drainages, 2000.

\begin{tabular}{|c|c|c|c|c|c|c|c|c|}
\hline \multirow[t]{2}{*}{ Habitat Type } & \multicolumn{2}{|c|}{ Milk River } & \multicolumn{2}{|c|}{ St. Mary River } & \multicolumn{2}{|c|}{ Lee Creek } & \multicolumn{2}{|c|}{ Overall } \\
\hline & No. & $\begin{array}{c}\text { Percent } \\
\text { Occurrence }\end{array}$ & No. & $\begin{array}{c}\text { Percent } \\
\text { Occurrence }\end{array}$ & No. & $\begin{array}{c}\text { Percent } \\
\text { Occurrence }\end{array}$ & No. & $\begin{array}{c}\text { Percent } \\
\text { Occurrence }\end{array}$ \\
\hline Backwater & 7 & 7.6 & & & & & 7 & 4.6 \\
\hline Flat (F3) & 4 & 4.3 & & & & & 4 & 2.6 \\
\hline Pool (P3) & 1 & 1.1 & & & & & 1 & 0.7 \\
\hline Run (R2) & 2 & 2.2 & & & & & 2 & 1.3 \\
\hline Run (R3) & 36 & 39.1 & 11 & 25.6 & 1 & 6.3 & 48 & 31.8 \\
\hline Run/Boulder Garden & 2 & 2.2 & & & & & 2 & 1.3 \\
\hline Riffle & 25 & 27.2 & 32 & 74.4 & 15 & 93.8 & 72 & 47.7 \\
\hline Riffle/Boulder Garden & 15 & 16.3 & & & & & 15 & 9.9 \\
\hline Grand Total & 92 & 100.0 & 43 & 100.0 & 16 & 100.0 & 151 & 100 \\
\hline
\end{tabular}

See Appendix B for definitions.

\section{Habitat Variables}

The relative abundance (CPUE) of shorthead sculpin and their associated habitat variables were analysed using Pearson Correlation and Linear Regression analyses to determine if relationships between abundance and habitat variables were evident. Habitat variables analysed included: depth and velocity at capture, discharge, D90, percent rock cover, percent turbidity cover, mean substrate size, and silt depth. None of the habitat variables analysed exhibited significant relationships with fish abundance $\left(\mathrm{r}^{2}<0.1\right.$ : Pearson Correlation Coefficient of $\mathrm{P}>0.05$ : Figure 3.17).

Although none of the habitat variables were significantly correlated to sculpin abundance, inferences from the data 
could still be drawn. Most depths at capture were shallow, with values ranging from 0.05 to $0.35 \mathrm{~m}$. Most velocities at capture ranged from 0.01 to $0.55 \mathrm{~m} / \mathrm{s}$, with a maximum velocity of $0.65 \mathrm{~m} / \mathrm{s}$. CPUE values $<5 \mathrm{fish} / \mathrm{min}$ were recorded at high and low discharges ( $\sim 14$ and $<1 \mathrm{~m}^{3} / \mathrm{s}$, respectively); however, CPUE $>10 \mathrm{fish} / \mathrm{min}$ were recorded only at discharges $<1 \mathrm{~m}^{3} / \mathrm{s}$. D 90 ranged from 0 to $0.9 \mathrm{~m}$. For percent rock cover, most values ranged from 0 to $55 \%$ for CPUE $<5 \mathrm{fish} / \mathrm{min}$, while CPUE $>7 \mathrm{fish} / \mathrm{min}$ were associated with 25 to $60 \%$ percent rock as cover. The percentage of turbidity as cover was low, with most values ranging from 0 to $5 \%$. Mean substrate size generally ranged from 2 to $22 \mathrm{~cm}$. Silt depth was generally low (0 to $0.01 \mathrm{~m}$ depths); the highest silt depth recorded was $0.03 \mathrm{~m}$, located in a side channel in the upper North Milk River.

Overall, the data suggests that shorthead sculpin generally use riffle and shallow run habitats, in low to moderate velocities and low silt depths. Substrate size consisted primarily of gravel and cobble. The distance of a captured fish from cover were also measured during sampling; most sculpins were closely associated with cover (i.e., distance from cover was approaching $0 \mathrm{~m}$ ), and rock was the predominant type of cover.

\subsubsection{Stonecat}

The habitat requirements of stonecat are poorly known (Scott and Crossman 1973; RL\&L 1987). Stonecats are most commonly associated with large substrate in deep pools and rocky bottoms in riffles of large streams; however, stonecats are apparently adaptable to many habitat types (Nelson and Paetz 1992). In the Milk River, stonecats have been located in areas with boulder rip-rap lining bridge abutments (i.e., at Deer Creek and Aden bridges; Clayton and Ash 1980; RL\&L 1987).

Spawning is presumed to occur in June or July in areas with large gravel or rocky substrate (Scott and Crossman 1973; Nelson and Paetz 1992). A mass of sticky eggs are deposited in nests beneath the rocks. Nests are guarded by both parents and the young-of-the-year probably rear in close proximity to the spawning site as both parents protect the young during early juvenile development (Brown 1971).

Stonecats feed primarily on aquatic insects and sometimes on small fishes, molluscs and plant material (Scott and Crossman 1973; Nelson and Paetz 1992). It is thought that they use barbels to locate food and they probably feed primarily at night (Nelson and Paetz 1992).

Overwintering of stonecats likely requires adequate stream flow and the presence of rocks for cover. The low winter flows in the Milk River may limit the distribution of suitable overwintering areas for stonecats (RL\&L 1987). 

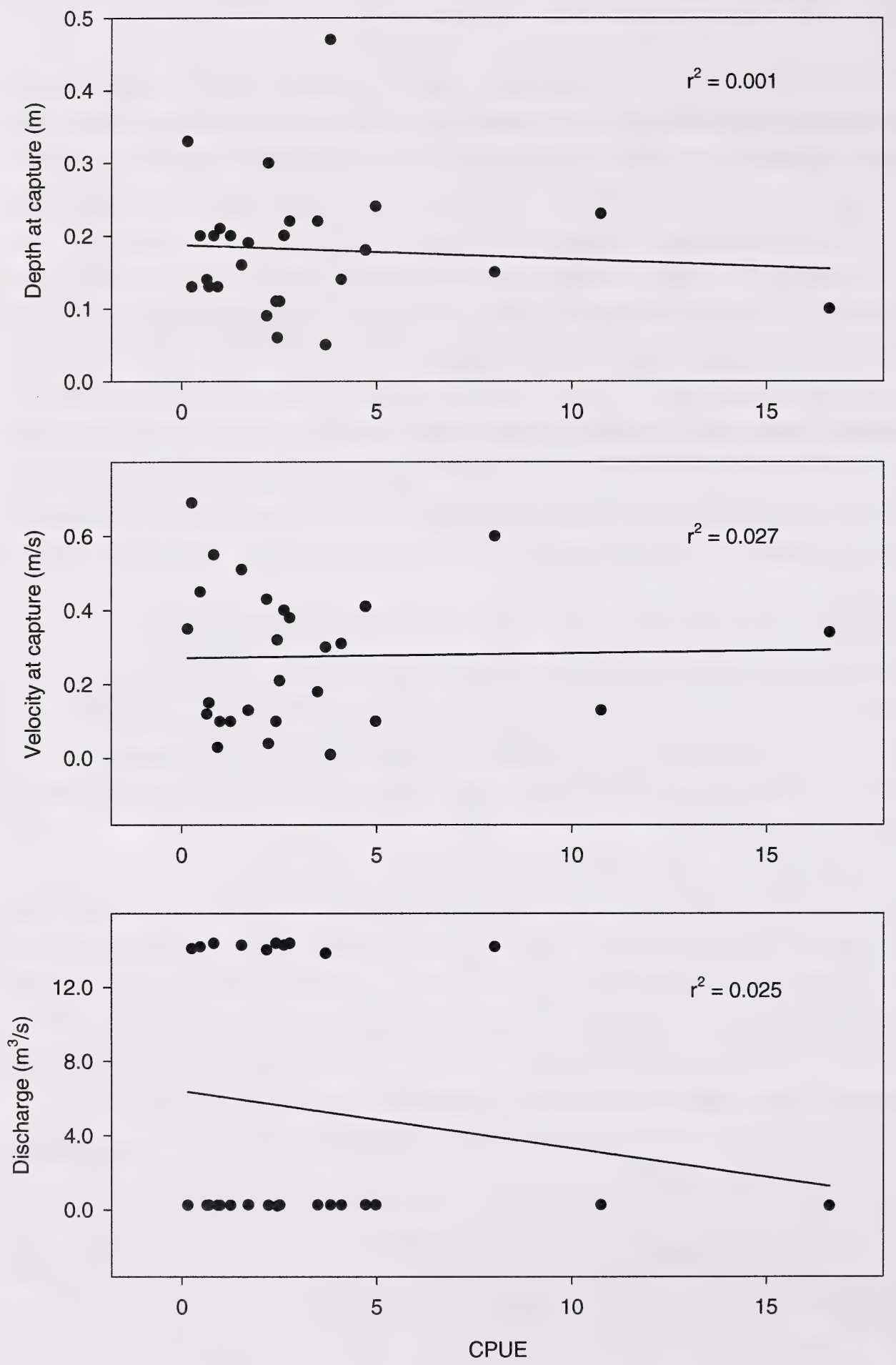

Figure 3.17 Linear regressions of habitat variables and the relative abundance (CPUE, no. fish/min) for shorthead sculpin in the Milk and St. Mary drainages, 2000. 

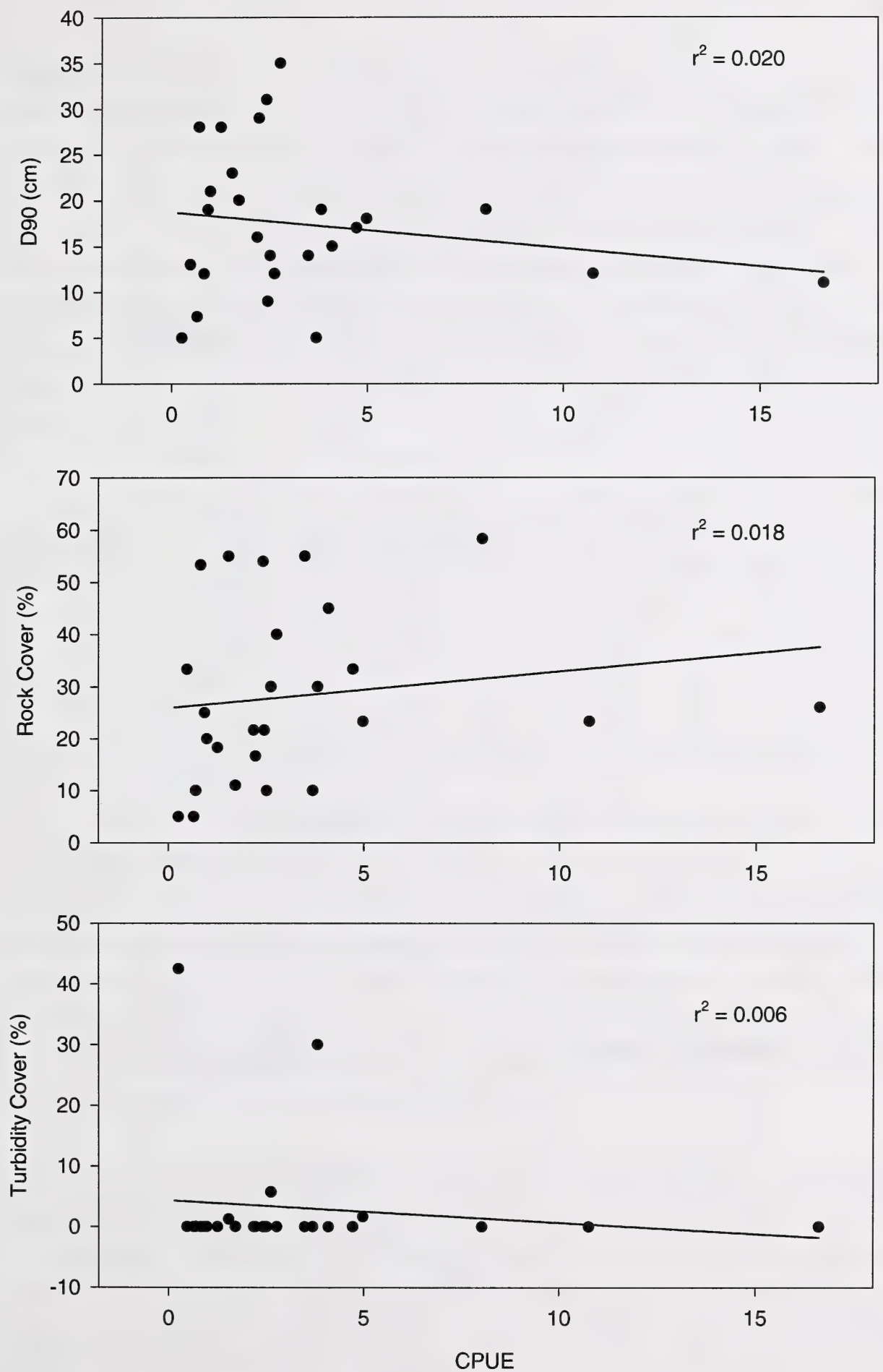

Figure 3.17 Continued 

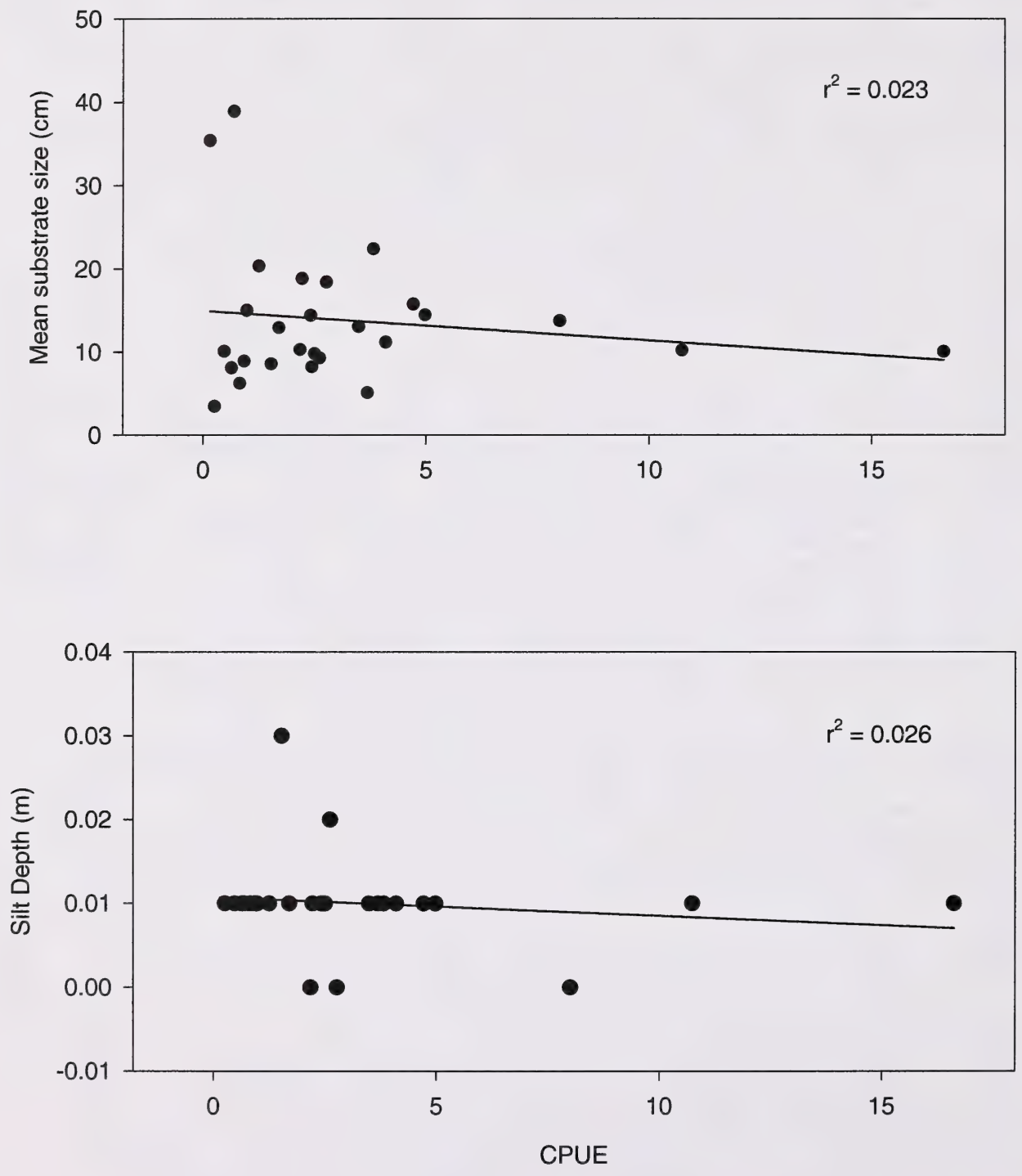

Figure 3.17 Concluded 


\section{Habitat Analyses}

Due to the small sample sizes at each site, data for all sites were combined. A One-sample T-test was performed to determine if significant differences existed for each of the habitat variables. All habitat variables were significantly different within the sample, with the exception of silt depth (Table 3.10). These results indicate that stonecat were not associated with specific habitat parameters, but rather were more "generalists" in relation to habitat use. Water depths at capture ranged from 0.1 to $0.6 \mathrm{~m}$, and velocity at capture ranged from 0.0 to $0.4 \mathrm{~m} / \mathrm{s}$. Mean substrate size was represented by large substrate $(21$ to $57 \mathrm{~cm})$. Percent area of rock as cover ranged from 10 to $60 \%$, with a mean of $30 \%$. The distance of a captured fish from cover was also measured during sampling; all stonecats were closely associated with cover (i.e., distance from cover was approaching $0 \mathrm{~m}$ ), and rock was the predominant type of cover.

Table 3.10 Summary of habitat variables for stonecat in the Milk River, 2000.

\begin{tabular}{|l|ccc|c|ccc|}
\hline Habitat Variable & $\mathbf{N}$ & Mean & Std. Deviation & Range & $\mathbf{t}_{0.05}$ & df & Significance \\
\hline Depth $(\mathrm{m})$ & 19 & 0.32 & 0.12 & $0.10-0.62$ & 11.64 & 18 & $0.000^{*}$ \\
Velocity $(\mathrm{m} / \mathrm{s})$ & 19 & 0.10 & 0.12 & $0.0-0.40$ & 3.58 & 18 & $0.002^{*}$ \\
D90 (m) & 13 & 0.44 & 0.19 & $0.19-0.90$ & 8.32 & 12 & $0.000^{*}$ \\
Silt Depth (m) & 13 & 0.03 & 0.04 & $0.005-0.1$ & 2.42 & 12 & 0.032 \\
Percent Rock as Cover & 13 & 30.38 & 17.26 & $10-60$ & 6.35 & 12 & $0.000^{*}$ \\
Mean Substrate size (cm) & 12 & 37.39 & 11.75 & $20.6-56.9$ & 11.02 & 11 & $0.000^{*}$ \\
\hline
\end{tabular}

* indicates significance at $\mathrm{P}<0.05$.

\subsubsection{Western Silvery Minnow}

Very little is known about the biology and habitat requirements of the western silvery minnow (Houston 1998; Nelson and Paetz 1992). Silvery minnow prefer quiet waters in rivers with slow to moderate velocity or in weedy inshore waters of lakes (Willock 1969; Scott and Crossman 1973; Jones et al. 1978). Substrates generally consist of mud, sand, and gravel substrates, but those that are not covered by silt (Trautman 1957; Willock 1969; Jones et al. 1978). Willock (1969) reported that unlike the brassy minnow, the silvery minnow was not captured in small tributaries, but rather in the mainstem habitats of the Milk River.

Spawning probably occurs in heavily vegetated backwaters in slower moving water (Scott and Crossman 1973; Houston 1998). It is believed that silvery minnows spawn in May, although no observations have been published (Scott and Crossman 1973; Houston 1998). This species lays non-adhesive eggs over riffles or in quiet backwater areas that are shallow and well-vegetated (Raney 1939). Trautman (1957) determined that spawning only occurs in areas of low silt deposition.

Rearing of the silvery minnow occurs near quiet shoreline areas and in the vicinity of tributary mouths, where they appear in small schools along the shore in emergent vegetation (Raney 1939 from Houston 1998; RL\&L 1987). The diet of silvery minnow consists primarily of algae (Willock 1969; RL\&L 1987; Nelson and Paetz 1992). 
In the Milk River, overwintering habitat for the western silvery minnow may be limited in some years due to low winter flows and insufficient water depths; however, RL\&L (1987) noted that based on the capture during November (Clayton and Ash 1980), overwintering is possible in the lowermost reaches of the Milk River.

In the present study, too few western silvery minnow $(n=2)$ were captured to allow statistical analyses of habitat variables. However, the two individuals captured were encountered in shallow flat and run habitat types (mean depths of $0.3 \mathrm{~m})$, with low to moderate velocities $(0.1$ and $0.4 \mathrm{~m} / \mathrm{s})$. The substrate consisted predominantly of sand ( $>85 \%$ composition), with low silt deposition $(<0.01 \mathrm{~m})$.

A study currently being conducted by in the Milk River from the International Boundary Crossing downstream to the Fresno Reservoir in Montana, determined that western silvery minnow were encountered in flat and run habitat types ( $65 \%$ inside bend, $20 \%$ channel crossover, and $15 \%$ outside bend). Mean water depths were $0.55 \mathrm{~m}$ and mean velocities were $1.5 \mathrm{~m} / \mathrm{s}$. Substrate consisted primarily of silt and sand ( $46 \%$ and $53 \%$, respectively; data obtained from Sean Stash, Montana State University).

\subsubsection{Brassy Minnow}

Similar to the western silvery minnow, very little is known about the biology and habitat requirements of the brassy minnow (Scott and Crossman 1973; Nelson and Paetz 1992). Paetz and Nelson (1970) noted that this species occurs in areas of slow current in the Milk River and its associated tributaries. Willock (1969) recorded brassy minnow in a number of the tributaries flowing from the Sweetgrass Hills of Montana and indicated a preference for pool habitats. Dymond (1939; In Scott and Crossman 1973) reported that the brassy minnow inhabits cooler waters than the silvery minnow. Similarly, RL\&L (1987 and 2001) found that the range of silvery and brassy minnows did not overlap. However in contrast, Willock (1969) and Nelson and Paetz (1992) found that the distribution of these two species did overlap to a small degree.

Spawning probably occurs in May or June and it has been suggested that eggs are deposited in quiet water over a silt bottom (Scott and Crossman 1973). No information was available on the rearing or overwintering habitat of the brassy minnow. The diet of brassy minnow consists mainly of phytoplankton and other algae, zooplankton and some aquatic insects primarily feeds on algae (Willock 1969; RL\&L 1987; Nelson and Paetz 1992).

In the present study, too few brassy minnow ( $n=9$ at 2 sites) were captured to complete statistical analyses on habitat variables. However, brassy minnow were present in two very different habitat types in the Milk River. At Site 4 (mid-river), one brassy minnow was captured in fast flowing, riffle habitat. Water depths were $0.12 \mathrm{~m}$ and velocities were $0.6 \mathrm{~m} / \mathrm{s}$. The substrate consisted predominantly of gravel ( $>85 \%$ composition), with low silt deposition $(<0.01 \mathrm{~m})$. D90 was $0.05 \mathrm{~m}$. The river was quite turbid $(10.3 \mathrm{NTU})$ at the time of sampling, with water transparencies of $0.15 \mathrm{~m}$. 
Brassy minnow $(n=8)$ were also captured in a deep, backwater area in the lower Milk River. Maximum depth in the backwater was $1.1 \mathrm{~m}$ and velocity was negligible $(<0.01 \mathrm{~m} / \mathrm{s})$. Substrate consisted predominantly of sand $(>90 \%$ composition) and some silt (silt depth of $0.01 \mathrm{~m}$ ). Cover types included depth and turbidity ( $15 \%$ area) and large woody debris $(10 \%)$.

\subsubsection{Sauger}

Sauger occur in both lakes and rivers within their geographic range. However, in Alberta, sauger are found only in rivers (Nelson and Paetz 1992). Sauger appear to be tolerant of silty waters, such as those of the Milk River and South Saskatchewan. Spawning occurs in the spring (end of May/beginning of June) over gravel and boulder substrate (Scott and Crossman 1973). This species feeds mostly on small fishes and aquatic insects (Nelson and Paetz 1992).

Willock (1968) found that sauger in the Milk River are commonly associated with pools containing rocky substrate. The author also suggested that the more eastern tributaries are the major spawning grounds for this species in the Milk River, since young saugers were captured at these locations, but were absent from similar habitats in tributaries farther west.

In the present study, 19 sauger were captured at 3 sites. Most sauger were captured in the lower Milk River at Site 22 (Aden Bridge; $n=17$ ). Results indicate that sauger in the Milk River were present in shallow flat and run habitat types (depths of 0.4 to $0.9 \mathrm{~m}$ ), with low to moderate velocities $(0.1$ and $0.4 \mathrm{~m} / \mathrm{s}$; Table 3.11$)$. Substrate consisted predominantly of sand ( $56 \%$ composition) and boulder ( $28 \%)$. All sites had low silt deposition $(0.01 \mathrm{~m})$. Cover type consisted primarily of depth and turbidity (mean of $32 \%$ area) and rock (mean of $6 \%$ area).

Table 3.11 Summary of habitat variables for sauger in the Milk River, 2000.

\begin{tabular}{|lccccc|}
\hline Habitat Variable & N & Mean & Minimum & Maximum & Std. Deviation \\
\hline Depth at capture $(\mathrm{m})$ & 5 & 0.63 & 0.40 & 0.86 & 0.18 \\
Velocity at capture $(\mathrm{m})$ & 5 & 0.09 & 0.01 & 0.37 & 0.16 \\
D90 $(\mathrm{m})$ & 2 & 0.45 & 0.38 & 0.52 & 0.10 \\
Silt depth $(\mathrm{m})$ & 3 & 0.01 & 0.01 & 0.01 & 0 \\
\hline
\end{tabular}

\subsubsection{Habitat Suitability for the Species at Risk}

\section{Shorthead Sculpin}

Shorthead sculpin were moderately abundant throughout the St. Mary River and most of the Milk River (low abundance in the lowermost sites). This indicates that spawning, rearing, and feeding habitat for shortheaci sculpin are not limiting within these systems. Similarly, overwintering habitat is well represented in both rivers, provided there is adequate stream flows. Surveys conducted in winter 1979/1980 and 1986 confirmed the presence of shorthead sculpin overwintering throughout the Milk River (Clayton and Ash 1980; RL\&L 1986; Figure 3.18). 

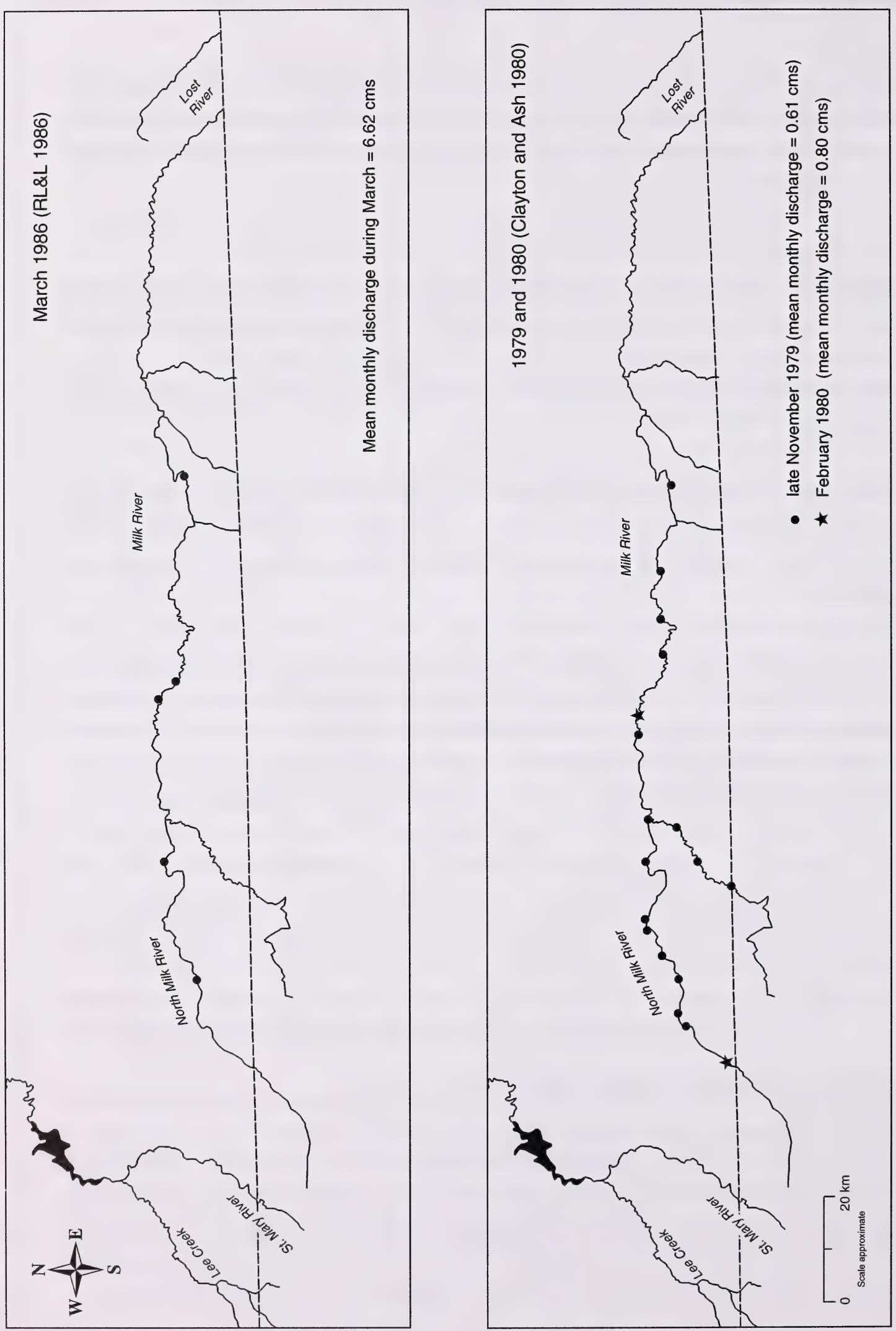

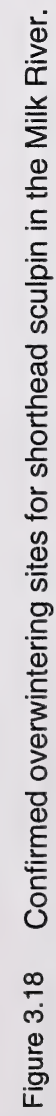


Mean monthly discharge during these years were average to above average compared to historical data ( $\sim 0.6$ to $0.8 \mathrm{~m}^{3} / \mathrm{s}$ in $1979 / 1980$ and $6.6 \mathrm{~m}^{3} / \mathrm{s}$ in 1986). In December 2000 , the mean monthly discharge was considerably less than that recorded in November $1979\left(0.2 \mathrm{~m}^{3} / \mathrm{s}\right.$ and $0.6 \mathrm{~m}^{3} / \mathrm{s}$, respectively). As such fish may be subjected to unsuitable habitat conditions during the winter of $2000 / 2001$.

\section{Stonecat}

Stonecats are generally associated with large substrate during the various life requisite functions (i.e., spawning, rearing, feeding, and overwintering). In the Milk River, stonecat were distributed primarily in the mid to lower reaches. In the lower reaches, coarse substrate was not prevalent but occurred in isolated patches. Stonecats often occupied these isolated patches where available. In the mid reaches of the Milk River, high quality habitats were located between Gold Spring Park and the Weir Bridge (i.e., presence of extensive areas of boulder-garden habitat types). A potential rearing site based on the high abundance of juvenile stonecat captured ( $1.5 \mathrm{fish} / \mathrm{min})$ was located at Site 25. Overwintering habitat for stonecats is likely limited in the Milk River during most years due to the very low winter flows (see Figure 3.16). In November 1979, numerous stonecats ( $n=29)$ were captured from a pool in the vicinity of the Deer Creek Bridge, indicating probable overwintering use in that area (Clayton and Ash 1980). During the present study, no pools were observed in this particular vicinity (maximum depth in 2000 was $0.65 \mathrm{~m}$ ), indicating low overwintering suitability.

\section{Western Silvery Minnow}

Rearing habitat for western silvery minnow consists of quiet waters in rivers with slow to moderate velocity (Willock 1969; Scott and Crossman 1973). This type of habitat, as well as suitable feeding areas for the western silvery minnow appear to be abundant in the lower reaches of the Milk River. Overwintering habitat has also been documented in the lower reaches of the Milk River. Clayton and Ash (1980) documented two silvery minnows in the vicinity of the Deer Creek bridge. Although overwintering areas have previously been documented, low winter flows may reduce overwintering potential in some years (e.g., winter 2000/2001). Although suitable rearing, feeding, and overwintering habitat appears to be widely available in the lower Milk River, few western silvery minnow have been documented. Other factors are evidently influencing their distribution and abundance in this river system.

Previous investigators have speculated about possible factors limiting the abundance of western silvery minnow in the Milk River. Trautman (1957) determined that similar to the eastern silvery minnow, the western silvery had a low tolerance for suspended sediment. He suggested that increased turbidity was responsible for the extirpation of the eastern silvery minnow in Ohio and could affect the status of the western silvery minnow (from Houston 1998). Willock (1968) also suggested that the loss of silvery minnow from extensive areas in the US was attributed to increased turbidity and the disappearance of aquatic vegetation due to heavy silt deposition. Willock (1968) speculated that prior to 1900 , the silvery minnow may have been well established in the upper reaches of the Milk River. He concluded that the population likely declined rapidly in the early 1900 's due to large increases in turbidity 
from the diversion of irrigation water into the Milk River. Houston (1998) indicated that the habitat potential of the western silvery minnow could be limited by habitat degradation, including agricultural activities.

\section{Overall Limiting Habitat Characteristics in the Milk River}

The habitat features limiting fish productivity in the Milk River include low winter flows, high suspended sediment levels, high siltation of the substrate, low winter dissolved oxygen (levels as low as $1.6 \mathrm{mg} / \mathrm{L}$; Noton 1980) in some years, and limited availability of refugia (RL\&L 1987). 


\subsection{SUMMARY AND RECOMMENDATIONS}

In assessing the status of the fish Species of Concern within the Milk and St. Mary river drainages, two primary questions were to be addressed, including:

1) Are the populations of the three fish Species at Risk increasing, stable or declining?

2) What habitat variables are key to ensure the continued viability of the Species of Concern?

1) Are the populations of the Species at Risk increasing, stable or declining?

A definitive answer for Primary Question \#1 cannot be forwarded at this time. Data upon which to base comparisons of fish abundance between the present study and historical data were limited, particularly for western silvery minnow and stonecat. RL\&L (1987) and Paetz (1993) were the primary studies used in the comparison (See Section 3.1.3 Fish Abundance).

Results in Section 3.1.3 (Fish Abundance) indicate that the population of shorthead sculpin in the Milk and St. Mary rivers are "relatively stable" but are characterized by low to moderate abundances. Shorthead sculpin were absent from the upper Milk River (i.e., it was dry in 2000), although this species has previously been documented in this section of river.

In general, the abundance of shorthead sculpin in the Milk River in 1986 and 2000 was similar. In 2000, mean CPUE values during fall were $0.9 \mathrm{fish} / \mathrm{min}$ in the mainstem and $5.9 \mathrm{fish} / \mathrm{min}$ in the North Milk River. In contrast, Paetz (1993) determined that CPUE values in 1989 were higher at two sites on the mainstem Milk River ( $>5$-fold higher). Although large differences in abundance were determined in the two studies, a survey by Stantec (2000) revealed similar results to the present study (CPUE for both studies was $0.3 \mathrm{fish} / \mathrm{min}$ ). The large differences in abundance between the 1989 and 2000 studies could be related to sampling biases (i.e., sampling only key habitat areas within a site as opposed to sampling representative areas within a site). Slight differences in abundance were also noted between Paetz (1993) and the present study in the St. Mary River and Lee Creek. These differences could be attributable to year-to-year variations in the population or related to sampling gear biases.

The population of stonecat in the Milk River appears "relatively stable", but is characterized by low abundance. Results in Section 3.1.3 (Fish Abundance) indicate that stonecat were more abundant in 2000 than in 1986, but CPUE values were low in both years (highest recorded CPUE was $1.49 \mathrm{fish} / \mathrm{min}$ ).

Very few specimens of western silvery minnow have previously been documented in the Milk River (Willock 1969; Clayton and Ash 1980; RL\&L 1987) and few were documented in the present study. Based on present and historical data it is evident that the western silvery minnow is rare in the drainage. Houston (1998) suggested that the western 
silvery minnow should be considered "vulnerable" in Canada given its restricted distribution and rarity.

\section{2) What habitat variables are key to ensure the continued viability of the Species of Concern?}

The present study (which should be considered preliminary in scope and detail) was unable to identify specific habitat variables determining the distribution of the shorthead sculpin. However, the data indicates that shorthead sculpin generally occupy riffle and shallow run habitats, characterized by low to moderate velocities, and gravel and cobble substrate. These types of habitat variables were most prevalent in the mid to upper sections of the Milk and North Milk rivers, and throughout the St. Mary River.

During the present study, we were unable to identify specific habitat variables determining the distribution of stonecat. However, the results indicate that stonecat are generally associated with large rock substrates located in shallow flats, runs and riffle/boulder gardens; associated velocities were typically low to moderate. Although these types of habitat variables were present in the mid to upper sections of the Milk River, stonecat were primarily encountered in the mid to lower sections of the Milk River.

Western silvery minnow were present in very low numbers in the Milk River during 2000; as such, the collection of detailed habitat data was limited. However, the few individuals encountered were associated with sandy, shallow flat habitat types, characterized by low to moderate velocities, and low silt deposition.

Discharge likely represents one of the major habitat variables determining the distribution and viability of the three fish Species at Risk. In the Milk River system, discharge is influenced by water withdrawals for irrigation purposes. If stream flows are reduced substantially in a given year, particularly during winter, overwintering success for most fish species could be jeopardized. In 2000, discharges in December were at extremely low levels $\left(0.2 \mathrm{~m}^{3} / \mathrm{s}\right)$, representing the ninth lowest value in 90 years of data $(10 \%$ of the total discharges recorded; See Figure 3.16 in Section 3.2.1).

Habitat degradation caused by agricultural activity could also affect the continued viability of Species at Risk (Houston 1988), primarily through instream disturbance, bank erosion, and non-point source surface runoff causing increased sediment levels. Trautman (1957) and Willock (1968) suggested that the loss of silvery minnow from extensive areas in the US was attributed to increased turbidity (suspended sediment) and the disappearance of aquatic vegetation due to heavy sediment deposition.

\section{Recommendations}

Recommendations for future studies include:

To more accurately assess the status of the Species of Concern, future monitoring studies should be completed on a scheduled basis (i.e., every 3 years) using standardized methods (e.g., backpack electrofishing); sampling should occur during similar times of the year (e.g., fall) and be conducted in 
representative (index) sites;

Of the five Species of Concern, more detailed studies on the distribution, abundance, and habitat preferences of the western silvery and brassy minnows are required (i.e., due to their limited distribution); and

Additional data on the habitat preference of stonecat and shorthead sculpin is also required in order to gain a better understanding of the key habitat variables determining their distribution and continued viability in the Milk River system. 


\subsection{LITERATURE CITED}

Brown, C.J.D. 1971. Fishes of Montana. Big Sky Books, Montana. 207 p.

Henderson, N.E. and R.E. Peter. 1969. Distribution of fishes of southern Alberta. J. Fish. Res. Board Can. 26:325-338.

Houston, J. 1998. Status of the Western Silvery Minnow, Hybognathus argyritis, in Canada. Canadian FieldNaturalist 122(1):147-153.

Jones, P.W., F.D. Martin, and J.D. Hardy, Jr. 1978. Development of fishes of the mid-Atlantic Bight. Vol.I. Acipenseridae through Ictaluridae. Proj. FWS/OBS-78/12, Fish. Wildl. Serv., U.S. Dep. Inter., Washington, D.C. 366 p.

Nelson, J.S. and M.J. Paetz. 1992. The fishes of Alberta. The University of Alberta Press, Edmonton, Alberta. $437 \mathrm{p}$.

O’Neil, J. and L. Hildebrand. 1986. Fisheries resources upstream of the Oldman River Dam. Prepared for Alberta Environment, Planning Division, Edmonton, Alberta. 131 p. + App.

Paetz, M.J. 1993. A management plan for the St. Mary shorthead sculpin (Cottus sp.) in Alberta. Prepared for World Wildlife Fund Canada - Prairie for Tomorrow and Alberta Fish and Wildlife Division. 1993.

Paetz, M.J. and J. S. Nelson. 1970. The fishes of Alberta. The Queen's Printer, Edmonton, Alberta. 282 p.

Peden, A.E. and G. W. Hughes. 1984. Status of the Shorthead Sculpin, Cotus Confusus, in the Flathead River, British Columbia. Canadian Field-Naturalist 98(1):127-133.

Raney, E.C. 1939. The breeding habits of the silvery minnow, Hybognathus regius Girard. American Midland Naturalist 21: 674-680.

Clayton, T.D. and G.R. Ash. 1980. A fisheries overview study of the Milk River Basin. Prepared for Alberta Environment, Planning Division, Edmonton, Alberta. 93 p. + App.

RL\&L Environmental Services Ltd. 1986. Late winter fisheries study - Milk River Site 2 Dam. Prepared for Alberta Environment, Planning Division, Edmonton, Alberta. 29 p. + App.

RL\&L Environmental Services Ltd. 1987. An inventory of aquatic habitats and fish resources in the Milk River, Alberta. Prepared for Alberta Environment, Planning Division, Edmonton, Alberta. 80 p. + App.

Roberts, W.[E.] 1988. The sculpins of Alberta. Alberta Nat. 18(4):121-127;153.

Scott W.B. and E.J. Crossman. 1973.Freshwater fishes of Canada. Fish. Res. Board Can. Bull. 184. 966 p.

Stantec Consulting Ltd. 2000. Environmental Assessment of Highway 4 in the Vicinity of Milk River - Draft. Prepared for Alberta Infrastructure. Stantec Project Number 136-77312.

Trautman, M.B. 1957. Fishes of Ohio. Ohio State University Press, Columbus, Ohio. xviii+683 p.

Willock, T.A. 1968. New Alberta records of the silvery and brassy minnows, stonecat and sauger, with a preliminary list of fishes of the Milk River in Alberta. Canadian Field-Naturalist 82:18-23. 
Willock, T.A. 1969. The ecology and zoogeography of fishes in the Missouri (Milk River) drainage of Alberta. M.Sc. Thesis. Carleton University, Ottawa, Ontario.

\section{Personal Communication}

Sean Stash, M.Sc. candidate, Montana State University 
APPENDIX A

Site Data 
Appendix A Table 1. Information for sites sampled in the Milk and St. Mary Rivers Study Area, 2000.

\begin{tabular}{|c|c|c|c|c|c|}
\hline Waterbody & Site Label & Site No. & Zone & Easting & Northing \\
\hline \multicolumn{6}{|l|}{ Lee Creek } \\
\hline & D. Kiemele & 17 & $12 \mathrm{U}$ & 314479 & 5433476 \\
\hline & Town of Beazer & 18 & $12 \mathrm{U}$ & 318515 & 5442905 \\
\hline & Cardston's water intake & 19 & $12 \mathrm{U}$ & 329379 & 5448649 \\
\hline & Cardston & 20 & $12 \mathrm{U}$ & 332954 & 5452242 \\
\hline \multicolumn{6}{|l|}{ Lost River } \\
\hline & Hwy 502 Bridge & 1a & $12 \mathrm{U}$ & & \\
\hline \multicolumn{6}{|l|}{ Milk River } \\
\hline & Pinhorn Ranch & 1 & $12 \mathrm{U}$ & 509739 & 5441407 \\
\hline & Aden Bridge & 2 & $12 \mathrm{U}$ & 477843 & 5443424 \\
\hline & Writing-on-Stone Provincial Park & 3 & $12 \mathrm{U}$ & 455180 & 5436443 \\
\hline & Town of Milk River & 4 & $12 U$ & 421050 & 5443726 \\
\hline & W. Snow & 5 & $12 U$ & 412862 & 5445209 \\
\hline & Twin River Grazing Reserve & 6 & $12 \mathrm{U}$ & 388016 & 5431708 \\
\hline & P. Hilmer & 7 & $12 \mathrm{U}$ & 374268 & 5441279 \\
\hline & Hwy 62 Bridge & 8 & $12 \mathrm{U}$ & 370185 & 5439069 \\
\hline & F.Hoyt & 9 & $12 \mathrm{U}$ & 359500 & 5436424 \\
\hline & J. Hoyt & 10 & $12 \mathrm{U}$ & 356082 & 5431944 \\
\hline & Pinhorn Ranch & 21 & $12 U$ & 506923 & 5439254 \\
\hline & J. Ross (Milk River Cattle Co.) & 22 & $12 \mathrm{U}$ & 485109 & 5444104 \\
\hline & Deer Creek Bridge & 23 & $12 \mathrm{U}$ & 460864 & 5437221 \\
\hline & Weir Bridge & 24 & $12 \mathrm{U}$ & 448815 & 5439142 \\
\hline & C. Netts & 25 & $12 \mathrm{U}$ & 437670 & 5439840 \\
\hline & Coffin Bridge & 26 & $12 \mathrm{U}$ & 435006 & 5439026 \\
\hline & J. Chapman & 27 & $12 \mathrm{U}$ & 431058 & 5438732 \\
\hline & Goldspring Park & 28 & $12 \mathrm{U}$ & 427624 & 5438579 \\
\hline & G. Pittman & 29 & $12 \mathrm{U}$ & 429419 & 5439455 \\
\hline \multicolumn{6}{|l|}{ St. Mary River } \\
\hline & Rinehart Ranches & 11 & $12 \mathrm{U}$ & 332424 & 5432578 \\
\hline & Kimble Fairground & 12 & $12 \mathrm{U}$ & 337490 & 5439395 \\
\hline & Hwy 501 Bridge near Kimble & 13 & $12 \mathrm{U}$ & 337925 & 5439867 \\
\hline & W. Bust & 14 & $12 \mathrm{U}$ & 338358 & 5441658 \\
\hline & K. Jensen (Snake Creek Ranch) & 15 & $12 \mathrm{U}$ & 340093 & 5448552 \\
\hline & Hwy 5 bridge at Cardston & 16 & $12 \mathrm{U}$ & 335077 & 5454858 \\
\hline & Kimble Fairgrounds to W. Bust & 12 to 14 & $12 U$ & 337490 & 5439395 \\
\hline
\end{tabular}




\section{APPENDIX B}

Habitat Classification System 
A) Riffle - Portion of channel with increased velocity relative to Run and Pool habitat types; broken water surface due to effects of submerged or exposed bed materials; relatively shallow (less than $25 \mathrm{~cm}$ ) during moderate to low flow periods.

Riffle (RF) - Typical riffle habitat type; limited submerged or overhead cover for juveniles and adult life stages; coarse substrate

Riffle-Boulder Garden (RF/BG) - Riffle habitat type with significant occurrence of large boulders; availability of significant instream cover for juveniles (to lesser extent adults) at moderate to high flow events.

B) Rapids (RA) - Portion of channel with highest velocity relative to other habitat types. Deeper than Riffle (ranging from $25-50 \mathrm{~cm}$ ); often formed by channel constriction. Substrate extremely coarse; dominated by large cobble and boulder material. Instream cover provided in pocket eddies (P3) and associated with cobble/boulder substrate.

C) Run - Portion of channel characterized by moderate to high current velocity relative to Pool and Flat habitat; water surface largely unbroken. Deeper than Riffle habitat type. Can be differentiated into four types; deep-slow, deep-fast, shallow-slow, and shallow-fast.

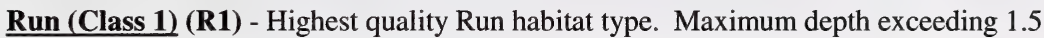
$\mathrm{m}$; average depth $1.0 \mathrm{~m}$. High instream cover at all flow conditions (submerged boulders/bedrock fractures, depth). Generally of deep-slow type (to lesser extent deep-fast) and situated proximal to upstream food production area (i.e., RF, R3).

Run (Class 2) (R2) - Moderate quality Run habitat type. Maximum depth reaching or exceeding $1.0 \mathrm{~m}$, generally exceeding $0.75 \mathrm{~m}$. High instream cover during all but low flow events (baseflow). Generally of either deep-fast type or moderately deep-slow type.

Run (Class 2)/Boulder garden (R2/BG) - Moderate quality Run habitat type; presence of large boulders in channel; high instream cover (boulder, bedrock fractures, turbulence) at all but low-flow events (baseflow). Depth characteristics similar to R2; however, required maximum depth lower due to cover afforded by boulders.

Run (Class 3) (R3) - Lowest quality Run habitat type. Maximum depth of $0.75 \mathrm{~m}$, but averaging $<0.50 \mathrm{~m}$. Low instream cover at all but high flow events. Generally of shallow-fast or shallow-slow types.

Run (Class 3)/Boulder garden (R3/BG) - Similar to R3 in depth and velocity characteristics; presence of large boulders in channel offers improved instream cover during moderate and high flow events.

D) Flat (FL) - Area of channel characterized by low current velocities (relative to RF and Run cover types); near-laminar (i.e., non-turbulent) flow character. Depositional area featuring predominantly sand/silt substrate. Differentiated from Pool habitat type on basis of high channel uniformity and lack of direct riffle/run association. More depositional in nature than R3 habitat (sand/silt substrate, lower food production, low cover, etc.).

Flat (Class 1) (F1) - High quality Flat habitat type. Maximum depth exceeding $1.5 \mathrm{~m}$; average depth $1.0 \mathrm{~m}$ or greater. 
Flat (Class 2) (F2) - Moderate quality Flat habitat type. Maximum depth exceeding $1.0 \mathrm{~m}$; generally exceeding $0.75 \mathrm{~m}$.

Flat (Class 3) (F3) - Low quality Flat habitat type. Maximum depth of $0.75 \mathrm{~m}$, averaging less than $0.50 \mathrm{~m}$.

E) Pool - Discrete portion of channel featuring increased depth and reduced velocity (downstream oriented) relative to Riffle and Run habitat types.

Pool (Class 1) (P1) - Highest quality Pool habitat type. Maximum depth exceeding 1.5 $\mathrm{m}$; average depth $1.0 \mathrm{~m}$ or greater; high instream cover at all flow-conditions (submerged boulder, bedrock fractures, depth, bank irregularities). Generally featuring high Riffle and/or Run association (i.e., food input). Often intergrades with deep-slow type of R1.

Pool (Class 2) (P2) - Moderate quality Pool habitat type. Maximum depth reaching or exceeding $1.0 \mathrm{~m}$, generally exceeding $0.75 \mathrm{~m}$. High instream cover at all but low flow events (baseflow).

Pool (Class 3) (P3) - Low quality pool habitat type. Maximum depth of $0.75 \mathrm{~m}$, averaging $<0.50 \mathrm{~m}$. Low instream cover at all but high flow events. Includes small pocket eddy type habitat.

\section{Citation:}

O'Neil, J. and L. Hildebrand. 1986. Fishery resources upstream of the Oldman River Dam. Prepared for Alberta Environment, Planning Division. R.L\&L. Report No. 181: 131 p. + 7 app. 


\section{APPENDIX C}

Fish Data 
Appendix C Table 1. Fish species encountered in Milk and St. Mary Rivers Study Area, 2000.

\begin{tabular}{|c|c|c|c|}
\hline Family & Common Name & Scientific Name & Code \\
\hline \multicolumn{4}{|l|}{ Salmonidae } \\
\hline & Cutthroat trout & Oncorhynchus clarki & CTTR \\
\hline & Mountain whitefish & Prosopium williamsoni & MNWH \\
\hline & Rainbow trout & Oncorhynchus mykiss & RNTR \\
\hline \multicolumn{4}{|l|}{ Cyprinidae } \\
\hline & Brassy minnow & Hybognathus hankinsoni & BRMN \\
\hline & Flathead chub & Platygobio gracilis & FLCH \\
\hline & Lake chub & Couesius plumbeus & $\mathrm{LKCH}$ \\
\hline & Longnose dace & Rhinichthys cataractae & LNDC \\
\hline & Western silvery minnow & Hybognathus argyritis & SLMN \\
\hline \multicolumn{4}{|c|}{ Catostomidae } \\
\hline & Longnose sucker & Catostomus catostomus & LNSC \\
\hline & Mountain sucker & Catostomus platyrhynchus & MNSC \\
\hline & Sucker species & Catostomus sp. & Suck sp. \\
\hline & White sucker & Catostomus commersoni & WHSC \\
\hline \multicolumn{4}{|l|}{ Ictaluridae } \\
\hline & Stonecat & Noturus flavus & STON \\
\hline \multicolumn{4}{|l|}{ Gadidae } \\
\hline & Burbot & Lota lota & BURB \\
\hline \multicolumn{4}{|l|}{ Percopsidae } \\
\hline & Trout perch & Percopsis omiscomaycus & TRPR \\
\hline \multicolumn{4}{|l|}{ Percidae } \\
\hline & Sauger & Stizostedion canadense & SAUG \\
\hline \multicolumn{4}{|l|}{ Cottidae } \\
\hline & Shorthead sculpin & Cottus sp. & SHSC \\
\hline & Unidentified & & UNID \\
\hline
\end{tabular}





National Library of Canada Bibliothèque nationale du Canada

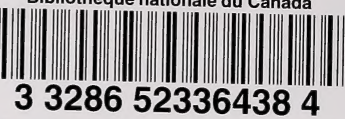

